Article

\title{
Air Quality Degradation by Mineral Dust over Beijing, Chengdu and Shanghai Chinese Megacities
}

\author{
Mathieu Lachatre ${ }^{1, *,+}\left(\mathbb{D}\right.$, Gilles Foret ${ }^{1}$, Benoit Laurent ${ }^{1}$, Guillaume Siour ${ }^{1}$, Juan Cuesta ${ }^{1}$, \\ Gaëlle Dufour ${ }^{1}{ }^{1}$, Fan Meng ${ }^{2}$, Wei Tang ${ }^{2}$, Qijie Zhang ${ }^{3}$ and Matthias Beekmann ${ }^{1}$ \\ 1 Laboratoire Inter-Universitaire des Systèmes Atmosphériques (LISA), UMR CNRS 7583, CNRS, Université \\ Paris Est Créteil et Université de Paris, Institut Pierre Simon Laplace, 94000 Créteil, France; \\ Gilles.Foret@lisa.u-pec.fr (G.F.); Benoit.Laurent@lisa.u-pec.fr (B.L.); guillaume.siour@lisa.u-pec.fr (G.S.); \\ Juan.Cuesta@lisa.u-pec.fr (J.C.); gaelle.dufour@lisa.u-pec.fr (G.D.); Matthias.Beekmann@lisa.u-pec.fr (M.B.) \\ 2 Chinese Research Academy of Environmental Sciences, Atmospheric Environment Institute, Beijing 100012, \\ China; mengfan@craes.org.cn (F.M.); tangwei@craes.org.cn (W.T.) \\ 3 Yunyiran Kinton Technology Co. Ltd., Nanchang 330000, China; jerry_eshk@163.com \\ * Correspondence: mathieu.lachatre@lmd.polytechnique.fr \\ † Current address: LMD/IPSL, École Polytechnique, Institut Polytechnique de Paris, ENS, PSL Université, \\ Sorbonne Université, CNRS, 91128 Palaiseau, France
}

Received: 14 May 2020; Accepted: 29 June 2020; Published: 2 July 2020

check for updates

\begin{abstract}
Air pollution in Chinese megacities has reached extremely hazardous levels, and human activities are responsible for the emission or production of large amounts of particulate matter (PM). In addition to PM from anthropogenic sources, natural phenomena, such as dust storms over Asian deserts, may also emit large amounts of PM, which lead episodically to poor air quality over Chinese megacities. In this paper, we quantify the degradation of air quality by dust over Beijing, Chengdu and Shanghai megacities using the three dimensions (3D) chemistry transport model CHIMERE, which simulates dust emission and transport online. In the first part of our work, we evaluate dust emissions using Moderate Resolution Imaging Spectroradiometer (MODIS) and Infrared Atmospheric Sounding Interferometer (IASI) satellite observations of aerosol optical depth, respectively, in the visible and the thermal infrared over source areas. PM simulations were also evaluated compared to surface monitoring stations. Then, mineral dust emissions and their impacts on particle composition of several Chinese megacities were analyzed. Dust emissions and transport over China were simulated during three years (2011, 2013 and 2015). Annual dust contributions to the $\mathrm{PM}_{10}$ budget over Beijing, Chengdu and Shanghai were evaluated respectively as $6.6 \%, 9.5 \%$ and $9.3 \%$. Dust outbreaks largely contribute to poor air quality events during springtime. Indeed it was found that dust significantly contribute for $22 \%, 52 \%$ and $43 \%$ of spring $\mathrm{PM}_{10}$ events (for Beijing, Chengdu and Shanghai respectively).
\end{abstract}

Keywords: mineral dust; air quality; modeling

\section{Introduction}

Chinese atmospheric pollution is a major health problem with more than $82 \%$ of Chinese population living in environment exceeding particulate matter $\left(\mathrm{PM}_{2.5}\right)$ concentrations of $75 \mu \mathrm{g} \mathrm{m}^{-3}$ [1] (Chinese National Standard GB 3095-2012 for $\mathrm{PM}_{2.5}$ in an urban environment, $24 \mathrm{H}$ mean: $75 \mu \mathrm{g} \mathrm{m}^{-3}$; annual mean: $35 \mu_{\mathrm{g} \mathrm{m}}{ }^{-3}$ ). During haze pollution events, $\mathrm{PM}_{2.5}$ levels have even exceeded $75 \mu \mathrm{g} \mathrm{m} \mathrm{m}^{-3}$ in 74 China major cities (800 million inhabitants) for 69\% of days in January 2013-reaching a daily concentration of $772 \mu \mathrm{g} \mathrm{m}^{-3}$ for $\mathrm{PM}_{2.5}$ [2]. A [3] recent study has aggregated chemical speciation from several Chinese cities and report that particle's composition is dominated by organic matter $(26.0 \%)$, sulfate $(17.7 \%)$, mineral dust $(11.8 \%)$, nitrate $(9.8 \%)$, ammonium $(6.6 \%)$ and elemental carbon 
(6.0\%). The People's Republic of China has seen its population exposed to strongly increasing pollution levels until the first decade of the 21st century. As a consequence, daily sunshine duration has been reduced [4] and premature mortality went up from 0.9 million in 2000 to more than 1.2 million $(+33 \%)$ in 2010 [5], while population increased only by $6 \%$ in the same time. Indeed, China has observed an important growth in several economic sectors such as transport increasing from 24 millions vehicles in 2003 to 78 millions vehicles in 2010 [6], energy production with an increase of $250 \%$ between 2000 and 2010 [7], construction and other sectors. To lower anthropogenic pollutants emissions, China has developed its environmental policy and tightened air quality standards, leading to a decrease of $\mathrm{PM}_{2.5}$ after 2007 [8] or latter for some components, as of $N O_{x}$ after 2012 [9]. Besides, China comprises extended arid areas, as the Taklimakan desert $\left(270 \times 10^{3} \mathrm{~km}^{2}\right)$, or the Gobi desert $\left(1.3 \times 10^{6} \mathrm{~km}^{2}\right)$ that naturally emit PM. As a result, Chinese air pollution is a mix of pollutants that come from a multitude of sources. Pollution sources will differently affect Chinese cities depending on their locations, their geographical situations or their meteorological situations.

Mineral dust aerosol from deserts represents about $40 \%$ of total aerosol mass emitted each year into the atmosphere [10]. Global dust emission estimates range from $1000 \mathrm{Mt}_{\text {year }}{ }^{-1}$ to $5000 \mathrm{Mt}$ year $^{-1}[11,12]$. The authors of [11] compile several model studies and estimate a global emission median value of $1572 \mathrm{Mt} \mathrm{year}^{-1}$. It is thus the most important aerosol component in term of mass for the global atmosphere. Mineral dust aerosol is characterized by a very high spatial and temporal variability, due to the episodic character of emission events associated to meteorological conditions like surface wind speed, and surface characteristics like protrusion elements. Dust aerosols must also be considered and study for their direct and indirect radiative impacts [13,14]. A previous study [15] has estimated that Chinese and Mongolian annual desert dust emissions between 1996 and 2001 are $240 \mathrm{Mt}$ year $^{-1}\left(+/-130 \mathrm{Mt} \mathrm{year}^{-1}\right)$ contributing to between 10 to $25 \%$ of global dust emissions. For spring time only, [16] found an emission of $252 \mathrm{Mt} \mathrm{year}^{-1}$. Mineral dust lifetime in the atmosphere can vary from few hours to several days, $[17,18]$ depending on meteorological conditions, and mineral dust particles can impact air quality of Chinese cities. Thus, dust can be transported over large areas and impact cities PM load: a one-year study, based on 2000, from [19] resulted in an annual dust average in $\mathrm{PM}_{2.5}$ fraction of $13 \mu \mathrm{g} \mathrm{m}^{-3}$ in Beijing and $7 \mu \mathrm{g} \mathrm{m}^{-3}$ in Shanghai (corresponding to about $12 \%$ of $\mathrm{PM}_{2.5}$ load in both cities). It shows high seasonal variability, with higher values in spring. In this study, maximum daily means dust content reaches $40 \mu \mathrm{g} \mathrm{m}^{-3}$ in Beijing and $30 \mu \mathrm{g} \mathrm{m}^{-3}$ in Shanghai. Recent studies have used Lagrangian modeling to determine the dust contribution to $\mathrm{PM}_{2.5}$ and $\mathrm{PM}_{10}$ in Chinese cities or study dust vertical diffusion and transport pathways [20,21]. Reference [20] has simulated dust plume over East China region and focused on a case study in spring 2015 which shows a large contribution of mineral elements to $\mathrm{PM}_{2.5}\left(34 \%\right.$ of $\left.\mathrm{Ca}^{2+}\right)$. The authors of [21] consider that dust plumes from Taklimakan are most commonly transported around $1.7 \mathrm{~km}$ above sea level.

In this work, we simulated mineral dust aerosol emissions from deserts and their transport across China. From these simulations, mineral dust impact on particulate matter load in several Chinese cities compared to anthropogenic pollution was studied. Three years were simulated (2011, 2013 and 2015) to study inter-annual variability and seasonal variations. In this study, we first evaluated the accuracy of modeled dust emissions, using satellite Aerosol Optical Depth (AOD) observations over source regions, then, we evaluated the regional simulated PM concentration with in situ measurements. Finally, the model capacity to represent PM chemical speciation on a daily basis and during several years allowed us to investigate the part of dust to PM average and peak burdens in several cities. It was also possible to determine dust burden from each desert area for each studied city. The results depend on the model ability to reproduce as correctly as possible for a long-term period the various geophysical processes that control Chinese cities air quality, from mineral dust emissions, transport to anthropogenic pollutants modeling. Thus, the CHIMERE model allows us to propose quantitative results and study the frequencies of pollution events controlled by dust transported to Chinese megacities, which brings additional information to the existing literature. 
Beijing, Chengdu and Shanghai are respectively the 2nd, 6th and 1st most populated cities in China, with 22.5, 14.5 and 24.5 million of inhabitants. These three cities also present different geographic situations, Beijing is located in Northern China ( $\left.39^{\circ} 54^{\prime} 13^{\prime \prime} \mathrm{N} ; 116^{\circ} 23^{\prime} 15^{\prime \prime} \mathrm{E}\right)$, Chengdu in Central China $\left(30^{\circ} 39^{\prime} 00^{\prime \prime} \mathrm{N} ; 104^{\circ} 04^{\prime} 00^{\prime \prime} \mathrm{E}\right)$ and Shanghai in Eastern China $\left(31^{\circ} 13^{\prime} 56^{\prime \prime} \mathrm{N} ; 121^{\circ} 28^{\prime} 09^{\prime \prime} \mathrm{E}\right)$. Beijing and Shanghai are in a similar monsoon system, with strong rainfall within summer season. Chengdu is located in a basin surrounded by plateau and high mountains (Tianshan, Qinling to the north) and climate, especially wind, is more continental and quite different. This induces different exposure to mineral dust pollution from sources mainly located in Western and Northern China (Cities location displayed later in the document). This choice is similar to cities selection made in previous work which reviewed observations of PM composition for representative Chinese megacities [22].

In Section 2, the paper first presents the material and method used in the study. Model and observations are described, then evaluation methods are explained. In Section 3, results are presented, starting with the characterization of mineral dust emissions, and then evaluating its contribution to urban particle pollution for the selected cities. Section 4 gives conclusions.

\section{Materials and Method}

\subsection{The CHIMERE Chemistry Transport Model}

In this work, we used the CHIMERE 3D regional chemistry transport model (CTM) $([23,24]$, $2014 \mathrm{~b}$ version) run over a $0.25^{\circ} \times 0.25^{\circ}$ regular grid. The domain is chosen large enough to include the Taklimakan desert on the West, Japan on the East and China's northern and southern territories $\left(72^{\circ} 30^{\prime} \mathrm{E}-145^{\circ} \mathrm{E} ; 17^{\circ} 30^{\prime} \mathrm{N}-55^{\circ} \mathrm{N}\right.$, simulation domain is displayed Figure 2). The domain is composed by 290 (longitude) $\times 150$ (latitude) grid cells and 17 vertical layers, from the ground to $200 \mathrm{hPa}$. Vertical layer thicknesses are increasing with altitude, 8 layers lie within the first $2 \mathrm{~km}$ of altitude. Advection is resolved using the Van Leer [25] second-order slope-limited transport scheme. Meteorological forcing is generated by ECMWF-IFS meteorological forecasts [26] and then interpolated to hourly resolution.

In our simulations, aerosols were distributed into 10 size-classes (also denoted as bins), from $0.05 \mu \mathrm{m}$ to $40 \mu \mathrm{m}$. 6 bins that correspond to $\mathrm{PM}_{2.5}, 2$ bins describe PM between $2.5 \mu \mathrm{m}$ and $10 \mu \mathrm{m}$ and finally 2 describe PM coarser than $10 \mu \mathrm{m}$. The model's AOD is calculated using a Fast-J photolysis scheme [27] and considering optical properties (Mie scattering, absorption) for each bin and each aerosols species.

\subsubsection{Anthropogenic and Biogenic Aerosols Modeling}

EDGAR-HTAP V2.2 emission inventories [28] based on 2010 were used to generate anthropogenic emissions (gaseous species and particulate matter). $\mathrm{NO}_{x}$ and $\mathrm{SO}_{2}$ emissions for 2013 and 2015 have been derived from remote sensing observation $\left(\mathrm{SO}_{2}\right.$ and $\mathrm{NO}_{x}$ columns from OMI instrument), with a method used and evaluated in [29], leading to decreases of $37 \%\left(\mathrm{SO}_{2}\right)$ and $21 \%\left(\mathrm{NO}_{x}\right)$ between 2011 and 2015, similar to recent inventory trends [30]. Biogenic emissions are generated by the MEGAN-v2 model [31]. Climatological boundary and initial conditions for dust are obtained from the GOCART global model [17] and from the LMDZ-INCA global model for others species [32,33].

Composition and phase state of inorganic aerosol is tabulated by using the ISORROPIA V2006 module [34]. It calculates the partitioning of $\mathrm{NH}_{3(g)} / \mathrm{NH}_{4(p)}^{+}, \mathrm{HNO}_{3(g)} / \mathrm{NO}_{3(p)}^{-}$, and $\mathrm{H}_{2} \mathrm{SO}_{4(p)} /$ $\mathrm{HSO}_{4(p)}^{-} / \mathrm{NO}_{3(p)}^{-}$, from the initial gaseous and particulate precursors content and meteorological conditions (temperature, relative humidity). Organic and inorganic species gas-phase chemistry is described with the reduced MELCHIOR2 mechanism [35], and the equilibrium for organic species between gas and particle phase is calculated using [36,37].

In this study, $\mathrm{PM}$ chemical speciation is divided into 8 different species (from 13 in our simulations): Dust (only representing the desert and natural fraction), $\mathrm{NH}_{4(p)}^{+}$(ammonium), $\mathrm{SO}_{4}^{2-}$ (sulfate), $\mathrm{NO}_{3(p)}^{-}$ (nitrate), AMPP (Anthropogenic Mineral Primary Particulate matter-including soil dust emitted 
from anthropogenic activities such as construction), OM (primary and secondary Organic Matter from biogenic and anthropogenic sources) , BC (Black Carbon) and SALT (sea salt).

\subsubsection{Mineral Dust Aerosol Modeling}

The CHIMERE model dust modeling was evaluated in a multi model comparison on Northern Chinese areas [38]. In this study, CHIMERE is the only model used and evaluate without need in tuning dust concentrations and which showed good performances.

Mineral dust emissions are a threshold phenomenon, which occurs when the wind friction force exercised on soil particle aggregates is higher than forces maintaining these aggregates on the ground. When a threshold wind friction velocity is exceeded, the wind kinetic energy will mobilize soil aggregates into a horizontal flux, a process called saltation. During saltation, soil aggregates go rolling along the surface, and then, shocks between aggregates and soil will liberate fine soil material from aggregates, in a process called sandblasting. The dust emission calculation requires a soil properties database (roughness length, texture and soil aggregates size distribution) as developed in [39] for China. Saltation fluxes are defined in [40] and calculated as follows (Equation (1)):

$$
F_{h}\left(D_{p}\right)=\frac{K \rho_{a i r} U^{* 3}}{g}\left(1-\frac{U_{t}^{*}}{U^{*}}\right)\left(1+\frac{U_{t}^{*}}{U^{*}}\right)^{2}
$$

where $U^{*}$ is the friction wind speed, $U_{t}^{*}$ is the threshold friction wind speed, calculated following Marticorena and Bergametti (1995). $K$ is constant with value equal to $1, \rho_{\text {air }}$ is the air density and the gravitational acceleration $g=9.8 \mathrm{~m} \mathrm{~s}^{-2}$.

The sandblasting process and vertical emission fluxes were calculated in CHIMERE from a parameterization by [41], which calculates the emission fluxes for a given aerosol size distribution, following Equation (2) [40]:

$$
F_{(v, m, i)}\left(D_{p}\right)=\sum_{k=1}^{N \text { class }} \frac{\pi \rho_{p} \beta p_{i}\left(D_{p, k}\right) d_{m, i}^{3}}{6 e_{i}} d F_{h}\left(D_{p}\right)
$$

where Nclass corresponds to the intervals of soil size distribution, $\mathrm{p}_{i}$ the relative fraction corresponding to Nclass, $\mathrm{e}_{i}$ is individual kinetic energy of aggregate, $\rho_{p}$ is particle density and $\beta$ an acceleration constant. We incorporated an optimization of emissions modeling, by adding a criterion on meteorological conditions. When the precipitation rate (inquired by ECMWF) is greater than $0.01 \mathrm{~kg}$ $\mathrm{m}^{-2} \mathrm{~h}^{-1}$, we assume an increase of binding energies in the soil that will inhibit the dust emissions for the next two hours.

Three dust size-distribution parameterizations based on a physical description of the emission processes are commonly used in models: [41-44], these parameterizations have been validated on a reduced set of data and the simulation of the dust size distribution remains uncertain mainly due to our ability to document correctly the soil properties at the emissions. The multi model evaluation [38] study included CHIMERE model with [41,43] parameterizations; finally the parameterization [41] was retained for their multi model comparison, due to better results. In our simulations $[41,45]$ was used, about $15 \%$ of dust emissions were distributed into $\mathrm{PM}_{2.5}$ (similar as [46]), 61\% were distributed into the coarse fraction of $\mathrm{PM}_{10}$ excluding $\mathrm{PM}_{2.5}\left(\mathrm{PM}_{2.5} / \mathrm{PM}_{10}=0.20\right)$, finally, $24 \%$ were distributed into a PM fraction with a diameter larger $10 \mu \mathrm{m}$, a fraction, which is not always considered [47]. This slightly differs from the $9.8 \%$ distribution proposed by $[43,47,48]$ for the mass distributed into the $\mathrm{PM}_{2.5}$ which might results to higher AOD at $550 \mathrm{~nm}$ close to source regions (AOD at that wavelength being particularly sensitive to particles between $0.5-1 \mu \mathrm{m}$ [49]). However, even if the chosen parameterization impacts the $\mathrm{PM}_{2.5} / \mathrm{PM}_{10}$ ratio, the study mainly focus on the $\mathrm{PM}_{10}$ fraction (76\% of total mass emitted in our case). The main issue to the $\mathrm{PM}_{2.5, \text { dust }} / \mathrm{PM}_{10, \text { dust }}$ distribution is finally the difference of transport behavior between the 2 particle range sizes, as the $\mathrm{PM}_{2.5, \text { dust }}$ fraction is most efficiently transported-the 
ratio increases to $0.32,0.25$ and 0.34 for Beijing, Chengdu and Shanghai respectively—which might induce an overestimation of $\mathrm{PM}_{10 \text {, dust }}$ mass.

CHIMERE model and modules are described in details in the model documentation.

In our study, simulations were performed for 2011, 2013 and 2015, to study inter annual variability of dust emissions. The years 2011 and 2013 were chosen because numerous dust events have been observed for those years [50,51]. However, these years were not abnormally high in total dust emissions from deserts [52] or in mineral dust detected in cities [53].

\subsubsection{Method to Determine Dust Origins in Cities}

To determine the contribution of each area to dust load in target cities, we successively inhibited dust emissions from the various arid areas to tag dust desert origin (Equation (3)).

$$
\text { Contribution }_{(n, i, t)}=\frac{(d u s t)_{(0, i, t)}-(d u s t)_{(n, i, t)}}{(d u s t)_{(0, i, t)}}
$$

where $(d u s t)_{(0)}$ represents the baseline simulation in which emissions are included for all areas, $n$ indicates computed simulations while inhibiting arid areas emissions, $i$ pixel locations and $t$ timestep. Simulations have been performed inhibiting one area at a time, and an additional simulation has been conducted by removing dust coming from outside the domain (i.e., boundary conditions) to evaluate their impact. This method will lead to some error in deposition process modeling, because deposition processes are non linear, depend on multiple factors such as meteorology, interactions between particles and soils with different types and properties [54,55]. The resulting underestimation for the dust concentration of $9 \%$ for Beijing, $8 \%$ for Chengdu and 13\% for Shanghai and is considered as still acceptable.

\subsection{AOD Data Set and Its Use for Model Evaluation}

Satellite based information from the Moderate Resolution Imaging Spectroradiometer (MODIS) instrument, based on the NASA Terra satellite, was used to evaluate simulated dust emissions, as in [56]. The MODIS AOD product was largely used to study particulate pollution and decently compared to other AOD products as AERONET or MISR [52]. The MODIS instrument provides a global sampling of the Earth once a day, passing around 10:30 a.m. at local time. It provides information on atmospheric column content as a combined Dark Target and Deep Blue $550 \mathrm{~nm}$ AOD product, on a $1^{\circ} \times 1^{\circ}$ resolution grid. Additionally, we compared AODs derived at $10 \mu \mathrm{m}$ from thermal infrared measurements of the Infrared Atmospheric Sounding Interferometer (IASI) onboard the MetOp-A satellite (overpass at 09:30 a.m. local time) with those calculated from simulated dust distributions by CHIMERE ([57], using a Mie code and Asian dust refractive indexes from). IASI-derived AODs in the thermal infrared are estimated with the newly-developed AEROIASI retrieval approach ([58,59], version 2$)$. We used CHIMERE simulations at 10:00 a.m. local time for the comparisons of AODs derived by both MODIS and IASI.

We first focused on dust emissions areas, to evaluate the simulated emissions. We verified that changes brought by dust emission inhibition by rainfall have improved correspondences between MODIS and CHIMERE AODs. For the 4 arid sub regions, AOD is mostly controlled by mineral dust, as mineral dust emissions represent more than $90 \%$ of the mass of total pollutant emissions for these regions.

The large dust emitting areas were divided into 4 regions (Figure 1) and compared to MODIS observations: the so-called Taklimakan desert area, which includes Taklimakan, the Kumtaq desert and the Qaidam desert; the Gobi desert, mainly situated over Mongolia; the Gurban desert, situated between the Taklimakan and Gobi desert; the last and smallest area, which is also the closest to China's biggest cities, contains several Chinese deserts (Tengger desert, Ulan Buh desert, Qubqi desert and Mu Us sandy land) and is called hereafter the Northern China desert. This separation of arid 
areas into smaller areas allows for a finer comparison between model and observations and a better analysis of dust variability; indeed the heterogeneity (especially in terms of emission frequencies) between each arid sub region is very important. The delimited sub-regions contain most of dust emissions, in our case, $\sim 98 \%$ of total dust emissions. The sub regions are different with respect to their emission/surface ratio (Table 1). Taklimakan is the main dust source region with $1460 \times 10^{3} \mathrm{~km}^{2}$. The Northern China desert region is the smallest area $\left(260 \times 10^{3} \mathrm{~km}^{2}\right)$, but is located closer to China East coast, and then to densely populated areas. The Mongolian Gobi desert is the largest area $(1630 \times$ $\left.10^{3} \mathrm{~km}^{2}\right)$, but is split into two areas, the Gurban Tunggut desert $\left(211 \times 10^{3} \mathrm{~km}^{2}\right.$; Called Gurban desert hereafter) and the main part of the Mongolian Gobi desert $\left(1104 \times 10^{3} \mathrm{~km}^{2}\right)$. It was necessary to split up the Mongolian Gobi Desert, as the temporality in dust emissions for the considered sub domains was different. Statistical results are presented in Table 2.
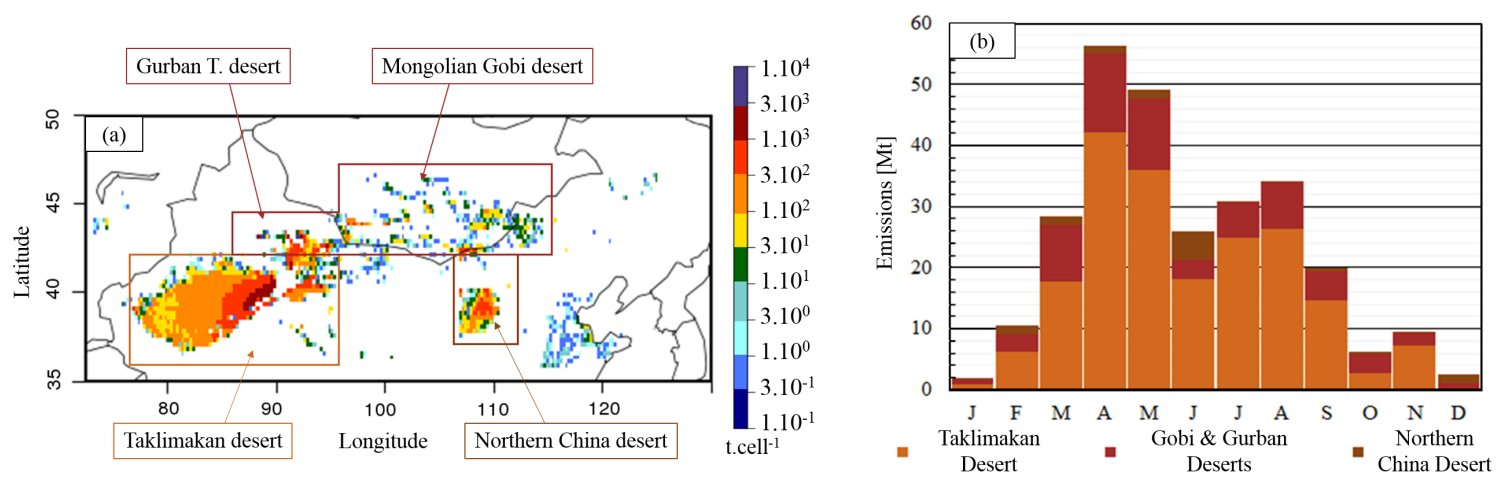

Figure 1. (a) Mean annual dust emissions from the main arid areas in Asia, simulated with CHIMERE for 2011, 2013 and 2015, in t cell $^{-1}$. (b) Monthly emissions for the main arid areas in Mt.

The AERONET network (AErosol RObotic NETwork, aeronet.gsfc.nasa.gov last consulted 09/30/2018) distributes observations of AOD for several wavelengths, and Ångström coefficients, with an hourly resolution for 2011, 2013 and 2015 in Beijing. Ångström coefficients provide information on particle size distribution in the atmospheric column, and can be calculated from AOD measurements at several wavelengths. Larger particles are characterized by lower Ångström coefficients and vice-versa. A value below 0.4 characterizes coarse particles such as dust [60].

Table 1. Mineral dust emissions from the different source regions, annual average calculated from 2011, 2013 ad 2015 simulations. Last column indicates the proportion of mineral dust emitted during the 5\% and $20 \%$ strongest emitting days.

\begin{tabular}{lcccc}
\hline Areas & $\begin{array}{c}\text { Mean Emissions } \\
(\mathbf{M t} \text { year } \\
\text { Contribution }\end{array}$ & $\begin{array}{c}\text { Standard } \\
\text { dev. (Mt) }\end{array}$ & $\begin{array}{c}\text { Emis/Surf } \\
\mathbf{( 1 0}^{-\mathbf{3}} \mathbf{t ~ k m}^{-\mathbf{2}} \mathbf{)}\end{array}$ & $\begin{array}{c}\text { \% of Mass Emitted } \\
\text { in 5\%/20\% } \\
\text { Strongest Days }\end{array}$ \\
\hline Taklimakan desert & $198 \mathrm{Mt} / 70 \%$ & $15 \mathrm{Mt}$ & 135 & $62 \% / 94 \%$ \\
Mongolian G. desert & $65 \mathrm{Mt} / 23 \%$ & $7 \mathrm{Mt}$ & 50 & $53 \% / 90 \%$ \\
Northern C. desert & $18 \mathrm{Mt} / 7 \%$ & $6 \mathrm{Mt}$ & 71 & $82 \% / 99 \%$ \\
Total domain & $283 \mathrm{Mt} /-$ & $28 \mathrm{Mt}$ & - & $54 \% / 87 \%$ \\
\hline
\end{tabular}

\subsection{Surface Measurements Data Set and Comparison Methods}

CHIMERE PM modeling in populated areas was also evaluated against $\mathrm{PM}_{2.5}$ and $\mathrm{PM}_{10}$ measurements from background stations close to cities, during spring periods and full years. We first wanted to assure that CHIMERE correctly models particulate pollution levels and variability in Beijing, Chengdu and Shanghai.

A comparison between model and hourly measurements from Chinese monitoring was performed from $\mathrm{PM}_{2.5}$ and $\mathrm{PM}_{10}$ spring season for 2013 (March-April) and 2015 (March-April-May). We focused 
our comparisons on these periods, because of data availability and because the dust impact was expected to be the strongest in spring. PM measurements are from TEOM instruments [61].

We first used a method to evaluate the representativeness of monitoring stations, from [62] which uses the relative diurnal variability of $\mathrm{SO}_{2}$ or $\mathrm{O}_{3}$, in order to evaluate if the considered stations were representative of rural, suburban, urban or traffic environment. This was motivated by the need to compare model simulations to monitoring stations with a coherent spatial resolution representativeness and in our case, stations near sources are not eligible. Based on [62] method results, the Beijing, Chengdu and Shanghai stations are located in a rural environment.

Additionally, similar information is also available for an other 30 stations located in a rural environment and 3 located in a suburban environment, located in 21 different cities. These stations were used to evaluate model performances on various areas, but the results are not detailed. Station locations can be found in Figure S5 (in the supplementary section).

Model versus measurement comparisons were conducted on an hourly basis, sampling model output depending on measurements' availability. Simulated model concentrations are bi-linearly interpolated at stations' coordinates.

We also used data from the U.S. Embassy and consulates over 3 cities (e.g., in Beijing, Chengdu and Shanghai, in urban background environment) to evaluate the $\mathrm{PM}_{2.5}$ correspondences over a larger period (2011, 2013 and 2015). $\mathrm{PM}_{2.5}$ is measured on an hourly basis with a MetOne BAM 1020 instrument [63]. It has to be noted that 2011 measurements are available only for Beijing. Comparison methods applied are the same as for previous comparisons, but daily values are calculated from hourly data depending on measurements availability, and compared.

Statistical results of comparisons, such as normalized bias, Normalized Root Mean Square Error (NRMSE) and correlation mean are presented in Tables 3 and 4 for spring seasons in 2011, 2013 and 2015 and in Figure S2 (in supplement).

\section{Results and Discussion}

\subsection{Dust Emissions and Evaluation}

\subsubsection{Mineral Dust Emissions and Seasonality}

Dust emissions yearly means for each desert areas are displayed in Table 1 and Figure 1a. The Taklimakan desert is the main dust source region with $198 \mathrm{Mt}^{-1} \mathrm{ear}^{-1} \mathrm{emissions}^{-1}$ We simulated 18.5 Mt year ${ }^{-1}$ dust emissions from the Northern China Desert $\left(71 \times 10^{-3} \mathrm{t} \mathrm{km}^{-2}\right)$. From the Mongolian Gobi desert $65.2 \mathrm{Mt} \mathrm{year}^{-1}$ were emitted $\left(50 \times 10^{-3} \mathrm{t} \mathrm{km}^{-2}\right)$. On average, total emissions reach about $283 \mathrm{Mt}$ year $^{-1}$, with $51 \%$ of mass emitted within spring season, $31 \%$ emitted in summer, $12 \%$ emitted in fall and about $6 \%$ emitted in winter (Figure 1b). A result close to [11], who indicate a median value of $294 \mathrm{Mt} \mathrm{year}^{-1}$ for Asia (standard deviation: $253 \mathrm{Mt} \mathrm{year}^{-1}$ ), obtained from an ensemble with 15 models. Lower results were obtained in [15,64] with values respectively of $242 \mathrm{Mt}$ (1996-2001 average; $\sigma=131 \mathrm{Mt}$ ) and $213 \mathrm{Mt}$ (2006 and 2010 average). The CHIMERE dust spatial distribution also fits results found in more recent study as [65].

Dust emissions can strongly vary from one year to another: for 2011, 2013 and 2015 respectively 321, 255 and $274 \mathrm{Mt}$ were emitted each year, which makes a $66 \mathrm{Mt}$ difference between the highest and lowest value (23\% of annual mean emissions). Compared to yearly emissions from (294 Mt, $242 \mathrm{Mt}, 213 \mathrm{Mt}[11,15,65])$, we concluded that 2011 emissions are slightly higher than mean values for emissions, but 2013 and 2015 represent average years.

Mean spring emissions for the three selected years are $145 \mathrm{Mt}$, slightly higher than in [66] with $120 \mathrm{Mt}$ (1960-2003 average), and lower than in [15] with values respectively of 182 Mt (1996-2001 average).

Table 1 presents the percent of dust emitted from the deserts during the $5 \%$ highest emitting days. For the Mongolian Gobi desert and the Northern China desert more than $80 \%$ of total dust mass is emitted during these days, which indicates intensive, but infrequent events. For the Taklimakan 
desert and the Gurban desert, more than $50 \%$ of mass is emitted during this subset of high emitting days, which still implies intense emissions events but with also more regular mineral dust emissions according to study of [15].

Figure 2 presents CHIMERE dust related $550 \mathrm{~nm}$ AOD over China (from ground to $200 \mathrm{hPa}$ ), for each season and, calculated from an 2011, 2013 and 2015 average. The largest AOD $_{\text {dust }}$ values near emissions areas occur during spring, and are efficiently transported over China and overseas (Figure 2). During summer season (Figure 2) AOD values over deserts are still high, but transport to Eastern China is not pronounced. This is due to particular meteorological conditions during the summer monsoon season, with high rainfall and southerly winds unfavorable for advection of dust to Eastern China. For winter and fall season, modeled dust emissions are low, and thus dust related AODs are low over emissions areas.

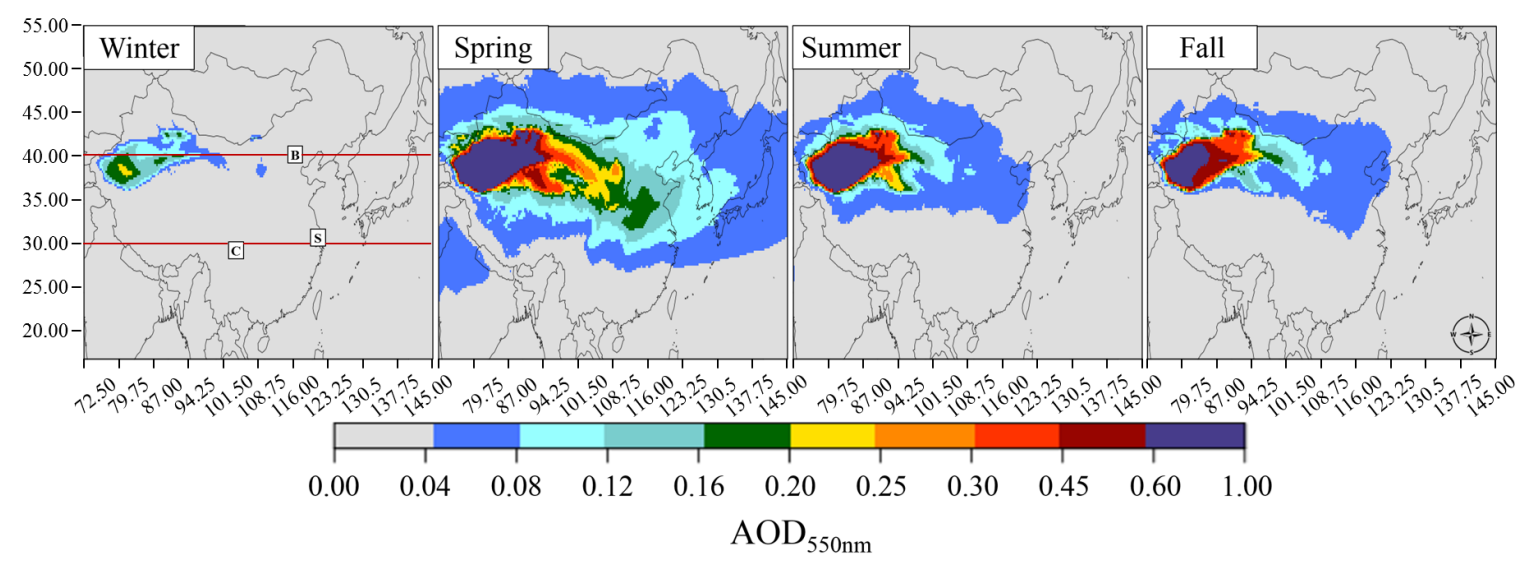

Figure 2. CHIMERE seasonal $550 \mathrm{~nm}$ Aerosol Optical Depth (AOD) associated to dust aerosols for Winter, Spring, Summer and Fall. Beijing (B), Chengdu (C) and Shanghai (S) locations are indicated on Winter map. Red lines on Winter map indicate $39.5^{\circ}$ and $31.0^{\circ}$ latitudes.

\subsubsection{CHIMERE AOD Evaluation in Dust Emission Source Areas}

Comparisons of CHIMERE AOD against MODIS AOD are gathered in Table 2, the table shows the temporal correspondences (day per day comparison of AOD values). We proceed to a comparison over the different areas for 2011, 2013 and 2015. Daily comparisons were conducted, calculating daily mean AOD for each sub domain with MODIS and CHIMERE outputs, filtering model data depending on MODIS pixels data availability. A daily sub-domain average value was accepted if at least $40 \%$ of MODIS data were available. Statistical information was calculated on time series (Bias $(\%)$, NRMSE $(\%)$ and Pearson correlation coefficient (r)) to estimate correspondences between model and satellite observations.

Table 2. Temporal correspondences between CHIMERE $550 \mathrm{~nm}$ AOD and MODIS $550 \mathrm{~nm}$ AOD, for 2011, 2013 and 2015 over main arid areas. NRMSE is the Normalized Root Mean Square Error. $r$ is the correlation coefficient. $n$ indicates number of daily mean value for sub domain.

\begin{tabular}{lcccr}
\hline Areas & Bias (\%) & NRMSE (\%) & r & n \\
\hline Taklimakan desert & $+50 \%$ & $159 \%$ & 0.74 & 1014 \\
Mongolian Gobi desert & $-31 \%$ & $60 \%$ & 0.51 & 897 \\
Gurban desert & $+64 \%$ & $161 \%$ & 0.54 & 937 \\
Northern China desert & $-10 \%$ & $65 \%$ & 0.66 & 862 \\
\hline
\end{tabular}

Figure S1 (in supplements) represents the $550 \mathrm{~nm}$ AOD spatial distributions in a $1^{\circ} \times 1^{\circ}$ resolution for 2011, 2013 and 2015, as measured by the MODIS instrument and modeled by CHIMERE. Statistical results for AODs spatial distribution comparisons are resumed in Table S1 (in the supplementary section). A similar spatial pattern between simulation and observations can be noted corresponding to 
a Pearson correlation coefficient of 0.68 . For most of the grid cells, CHIMERE AOD underestimates MODIS values (bias $=-40 \%$ ), excepted over Taklimakan and Gurban desert areas, where AOD are overestimated (bias $=+50 \%$ and $+64 \%$ respectively). Thus, this overestimation could partly be induced by an excessive distribution of mineral dust mass into $\mathrm{PM}_{2.5}$.

Indeed, CHIMERE AOD mainly overestimates MODIS AOD for the two most dust emitting areas, but a good daily correlation is obtained (Pearson correlation coefficient $r=0.74$ for Taklimakan and $r=0.54$ for the Gurban desert). This statement is also verified for the Mongolian Gobi desert and the Northern Desert ( $r=0.51$ and $r=0.66$ respectively). These correlations show that the model reproduces at least part of the dust emissions events in a correct timing.

Comparisons for 2011, 2013 and 2015 separately have shown similar results for 2011 and 2013. As for Taklimakan example Pearson correlation coefficients equal $r_{2011}=0.76 ; r_{2013}=0.77$ bias equal $+59 \%$ and $+51 \%$. In 2015 , Pearson correlation coefficient is 0.69 and bias equals $+39 \%$. The same variability is found for Northern China desert area. For Mongolian Gobi desert, slightly more variability is found between the three years, as for Mongolian Gobi desert area, Pearson correlation coefficient equal $r_{2011}=0.60, r_{2013}=0.41$ and $r_{2015}=0.50$, nonetheless bias is quite stable $(-35 \%,-27 \%$ and $-30 \%$ ). A similar variability is found for the Gurban desert area.

Additional information is gained from AEROIASI retrieval, deriving AOD at $10 \mu \mathrm{m}$. CHIMERE AOD for dust at $10 \mu \mathrm{m}$ was calculated to compare with an additional independent instrument particularly sensitive to the coarse fraction of aerosols. In this analysis only focusing on dust, we have evaluated the model ability to simulate the occurrence of dust events (with AODs larger than 0.2). Frequencies (in \%) of daily dust $10 \mu \mathrm{m}$ exceeding 0.2 in AEROIASI and CHIMERE are displayed on Figure 3, covering 2011, 2013 and 2015 period (used here for model evaluation, but not as a climatology). The AOD threshold is most likely to be exceeded in desert areas and both retrieval and model highlighted the same patterns. Similarly, as in the MODIS comparison, the Mongolian Gobi desert frequencies are underestimated and Taklimakan frequencies are slightly overestimated but well reproduced.

AEROIASI Frequency (\%) of Dust $10 \mu \mathrm{m}$ AOD $>0.2$ CHIMERE Frequency (\%) of Dust 10 $\mu \mathrm{m}$ AOD $>0.2$
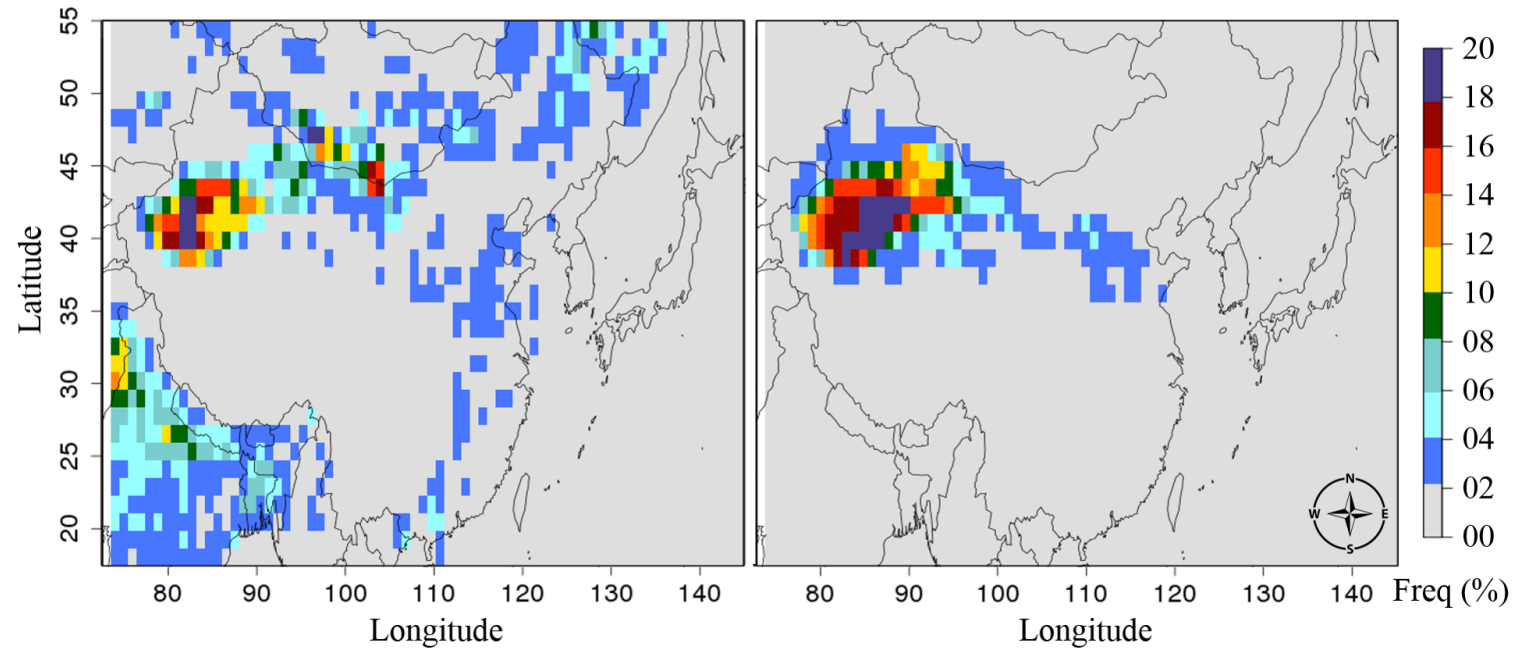

Figure 3. (left) AEROIASI Frequency (\%) of daily dust $10 \mu \mathrm{m}$ AOD > 0.2. (right) CHIMERE Frequency (\%) of daily dust $10 \mu \mathrm{m}$ AOD > 0.2. Frequencies are calculated over daily value for 2011, 2013 and 2015.

An additional comparison has been done between AEROIASI and CHIMERE AOD with the same criteria as done for the MODIS vs CHIMERE comparison. Similar results have been found for the Taklimakan area $(r=0.75, n=945, N R M S E=134 \%)$ with the notable exception for the bias (bias $=9 \%$ ), which is rather small and much lower than the bias with respect to MODIS AOD at $550 \mathrm{~nm}$. Distinctly of the $550 \mathrm{~nm}$ AOD, the $10 \mu \mathrm{m}$ AOD is mostly controlled by the coarser fraction of 
dust aerosol. This aspect provides reliability on the amounts of dust simulated by CHIMERE, since most of its mass corresponds to the coarse fraction of aerosols ( $85 \%$ of dust mass correspond to particle larger than $2.5 \mu \mathrm{m}$, q.v. Section 2.1).

\subsubsection{Dust Vertical Dispersion}

Over the Taklimakan area ( $39.5^{\circ}$ of latitude), CHIMERE simulations shows desert dust vertically transported up 4 and $8 \mathrm{~km}$ of altitude depending on the season, with a marked vertical gradient between the surface and the upper layers (see Figure 4 1st row). Such vertical distribution of dust with a marked gradient over several kilometers is consistent with a climatology (2007-2015) of desert dust vertical distribution over this area [67], done with measurements form the CALIOP instrument ([68,69], Cloud Aerosol Lidar with Orthogonal Polarization). However, dust plume transport appears to be more vertically spread in CHIMERE simulations than in the CALIOP climatology in which dust do not reach altitude higher than $6 \mathrm{~km}$, while in CHIMERE simulations they can reach $10 \mathrm{~km}$ of altitude. This excessive spreading in vertical transport modeling has already been observed for simulation of volcanoes plumes $[24,70,71]$, and it is a point which requires improvement (e.g., vertical transport scheme or vertical resolution). As a consequence, mineral dust plume is transported over the Himalayas (2nd row, $31.0^{\circ}$ of latitude) a path that is not observed in [67] and pollutant in plume can be excessively diffused, leading to low concentrations.

\subsection{Dust Contribution to Urban Chinese Particle Pollution}

\subsubsection{Evaluation of PM Concentration Modeling}

CHIMERE simulation results compared to measurements for $\mathrm{PM}_{10}$ and $\mathrm{PM}_{2.5}$ during 2013 and 2015 springs are displayed in Table 3. A model evaluation with surface measurements is necessary to quantify model skills and limits. As China is a large country with various pollution sources (anthropogenic or naturals), evaluation of surface concentrations is necessary to determine which cities present lower uncertainties in the available database to afterwards evaluate the impact of dust on PM load. PM content is underestimated in eastern and north - western areas, but slightly overestimated over central and southern China compared to measurements. Also, in these areas, NRMSE is smaller than over northern areas. The $\mathrm{PM}_{2.5}$ daily variation is better represented than $\mathrm{PM}_{10}$, with higher Pearson correlation coefficients.

Mean, normalized bias, NRMSE and correlation are presented in Table 3, for three selected cities. Normalized mean errors were calculated for $\mathrm{PM}_{2.5}$ and $\mathrm{PM}_{10}$, estimated respectively to $21 \%$ and $31 \%$. The authors of [72] suggest to evaluate PM modeling performances based on mean fractional bias and error statistical indicators, expressed as in Equations (4) and (5) respectively:

$$
\begin{aligned}
& M F B=\frac{1}{N} \sum_{i=1}^{N} \frac{\left(C_{m}-C_{o}\right)}{\left(C_{o}+C_{m} / 2\right)} \\
& M F E=\frac{1}{N} \sum_{i=1}^{N} \frac{\left|C_{m}-C_{o}\right|}{\left(C_{o}+C_{m} / 2\right)}
\end{aligned}
$$

where $C_{m}$ is the CHIMERE estimated concentration at $i$ station, $C_{o}$ the measured concentration at station $i$, and $N$ the number of available stations for the considered time period. The authors of [72] suggest that model performances for PM is fairly good for the considered period if MFB is lower than 0.3 and MFE lower than 0.5. Both criteria are met for $\mathrm{PM}_{2.5}(-0.002$ and 0.14$)$ and $\mathrm{PM}_{10}(-0.21$ and 0.24$)$ for MFB and MFE respectively (MFE and MFB values are calculated on all stations available in the dataset see Section 2.3). 


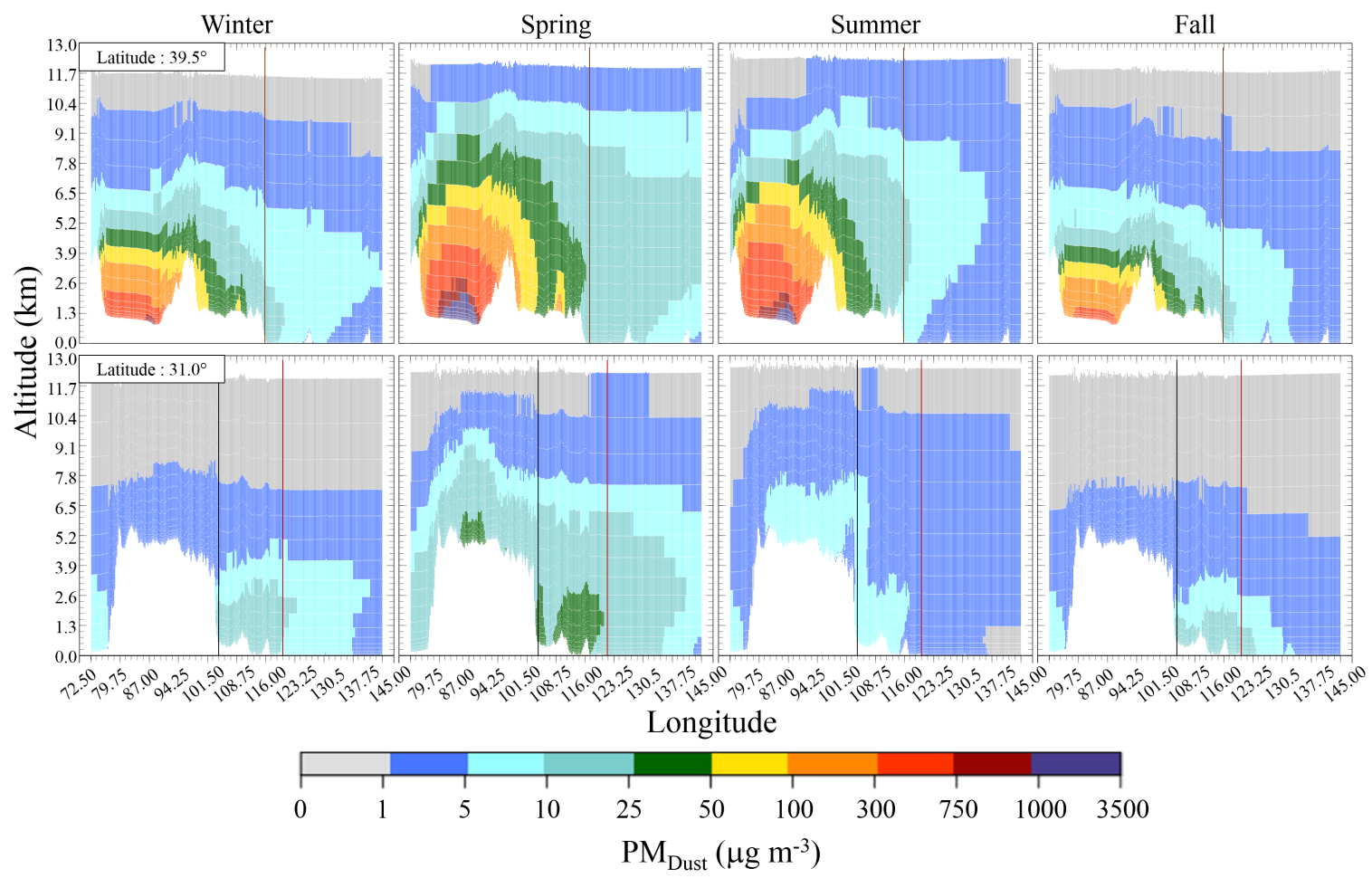

Figure 4. CHIMERE dust concentration vertical profiles longitude cut for winter (1st column), spring (2nd column), summer (3rd column) and fall (4th column). 1st row shows profiles for $39.5^{\circ}$ latitude, 2nd row shows profiles for $31.0^{\circ}$ latitude. Altitudes are calculated compared to sea level. All figures are produced with 2011, 2013 and 2015 data. Beijing is identified on 1st row by the brown vertical line, Chengdu is identified on 2 nd row by the black vertical line and Shanghai is identified on 2nd row by the red vertical line. Transect latitudes are displayed on Figure 2.

Table 3. CHIMERE Model $\mathrm{PM}_{10}$ and $\mathrm{PM}_{2.5}$ comparisons to hourly measurements from monitoring stations for springs 2013 and 2015. $n$ indicates number of hourly measurements.

\begin{tabular}{lccccc}
\hline Stations & Meas Mean & Bias (\%) & NRMSE (\%) & $\mathbf{r}$ & $\mathbf{n}$ \\
\hline Beijing PM $_{\mathbf{1 0}}$ & $120.7 \mu \mathrm{g} \mathrm{m}^{-3}$ & $-26 \%$ & $73 \%$ & 0.47 & 2921 \\
Chengdu PM & $165.1 \mu \mathrm{g} \mathrm{m}^{-3}$ & $-10 \%$ & $67 \%$ & 0.69 & 3533 \\
Shanghai $\mathbf{P M}_{\mathbf{1 0}}$ & $85.9 \mu \mathrm{g} \mathrm{m}^{-3}$ & $+5 \%$ & $47 \%$ & 0.69 & 2704 \\
\hline Beijing PM $_{\mathbf{2 . 5}}$ & $77.3 \mu \mathrm{g} \mathrm{m}^{-3}$ & $-6 \%$ & $57 \%$ & 0.77 & 3556 \\
Chengdu PM $_{2.5}$ & $82.5 \mu \mathrm{g} \mathrm{m}^{-3}$ & $+23 \%$ & $64 \%$ & 0.69 & 3648 \\
Shanghai $\mathbf{P M}_{\mathbf{2 . 5}}$ & $54.6 \mu \mathrm{g} \mathrm{m}^{-3}$ & $+19 \%$ & $55 \%$ & 0.69 & 3341 \\
\hline
\end{tabular}

We then evaluated $\mathrm{PM}_{2.5}$ over 2011, 2013 and 2015 for the three selected cities, from US embassy data. CHIMERE vs US embassy PM2.5 comparisons results for 2011, 2013 and 2015 are shown in Table 4. Daily time series for Beijing, Chengdu and Shanghai are displayed in Figure S2 (in supplement). 2011 measurements are available only for the Beijing station. The highest annual mean $\mathrm{PM}_{2.5}$ is observed in Beijing $\left(92.2 \mu \mathrm{g} \mathrm{m}^{-3}\right)$, and the lowest in Shanghai $\left(55.3 \mu \mathrm{g} \mathrm{m}^{-3}\right)$. Measurements show for all of the three stations a seasonal cycle, with highest pollution levels in winter and lowest pollution levels in summer. It was observed in available time series that Beijing, Chengdu and Shanghai exceed Chinese standard for daily $\mathrm{PM}_{2.5}\left(75 \mu \mathrm{g} \mathrm{m}^{-3}\right.$; Ambient Air Quality Standards-National Standard GB 3095-2012) respectively on $47 \%, 43 \%$ and $21 \%$ of available days. The daily $\mathrm{PM}_{2.5}$ variability is correctly represented in CHIMERE with Pearson correlation coefficients of $0.75,0.72$ and 0.76 in Beijing, Chengdu and Shanghai respectively. CHIMERE simulated $\mathrm{PM}_{2.5}$ overestimates measurements values, particularly in Chengdu (+52\%). Differences between measurements and simulations are larger 
in 2015, maybe because of a decreasing pollution trend not completely reproduced by 2010 based inventories [29]. CHIMERE also satisfies $\mathrm{PM}_{2.5}$ modeling performance goals as suggested by [72], with a MFB and MFE of 0.19 for the three stations for the considered period.

Table 4. CHIMERE model $\mathrm{PM}_{2.5}$ comparison to daily measurements from monitoring stations for 2011, 2013 and 2015. $n$ indicates number of daily mean measurements.

\begin{tabular}{|c|c|c|c|c|c|}
\hline Stations & Meas Mean & Bias (\%) & NRMSE (\%) & $\mathbf{r}$ & $\mathbf{n}$ \\
\hline Beijing $\mathrm{PM}_{2.5}$ & $94.2 \mu \mathrm{g} \mathrm{m}^{-3}$ & $+19 \%$ & $61 \%$ & 0.75 & 1085 \\
\hline Chengdu $\mathbf{P M}_{2.5}$ & $83.8 \mu \mathrm{g} \mathrm{m}^{-3}$ & $+52 \%$ & $69 \%$ & 0.72 & 687 \\
\hline Shanghai $\mathbf{P M}_{2.5}$ & $55.3 \mu \mathrm{g} \mathrm{m}^{-3}$ & $+24 \%$ & $57 \%$ & 0.76 & 723 \\
\hline
\end{tabular}

\subsubsection{Dust Contribution to Cities' Air Pollution and Dust Origin}

Figure $\mathrm{S} 4$ (in the supplementary section) presents $\mathrm{PM}_{10}$ and respective dust contributions for 2011, 2013 and 2015 spring seasons to $\mathrm{PM}_{10}$. As dust emissions present high variability (2015 emissions are $25 \%$ lower than 2011 emissions), dust impact to populated areas is also varying causing a significant change of dust contribution in Beijing (from 25\% in 2011 to 16\% in 2015), Chengdu (24\% to 18\%) and Shanghai ( $21 \%$ to $14 \%)$. It also can be noted that absolute $\mathrm{PM}_{10}$ values decrease between 2011 and 2015 .

Figure 5 shows the monthly variability of dust contributions to $\mathrm{PM}_{10}$ in three Chinese cities, Beijing, Chengdu and Shanghai. The specific desert mineral dust is originating from is also displayed on Figure 5.

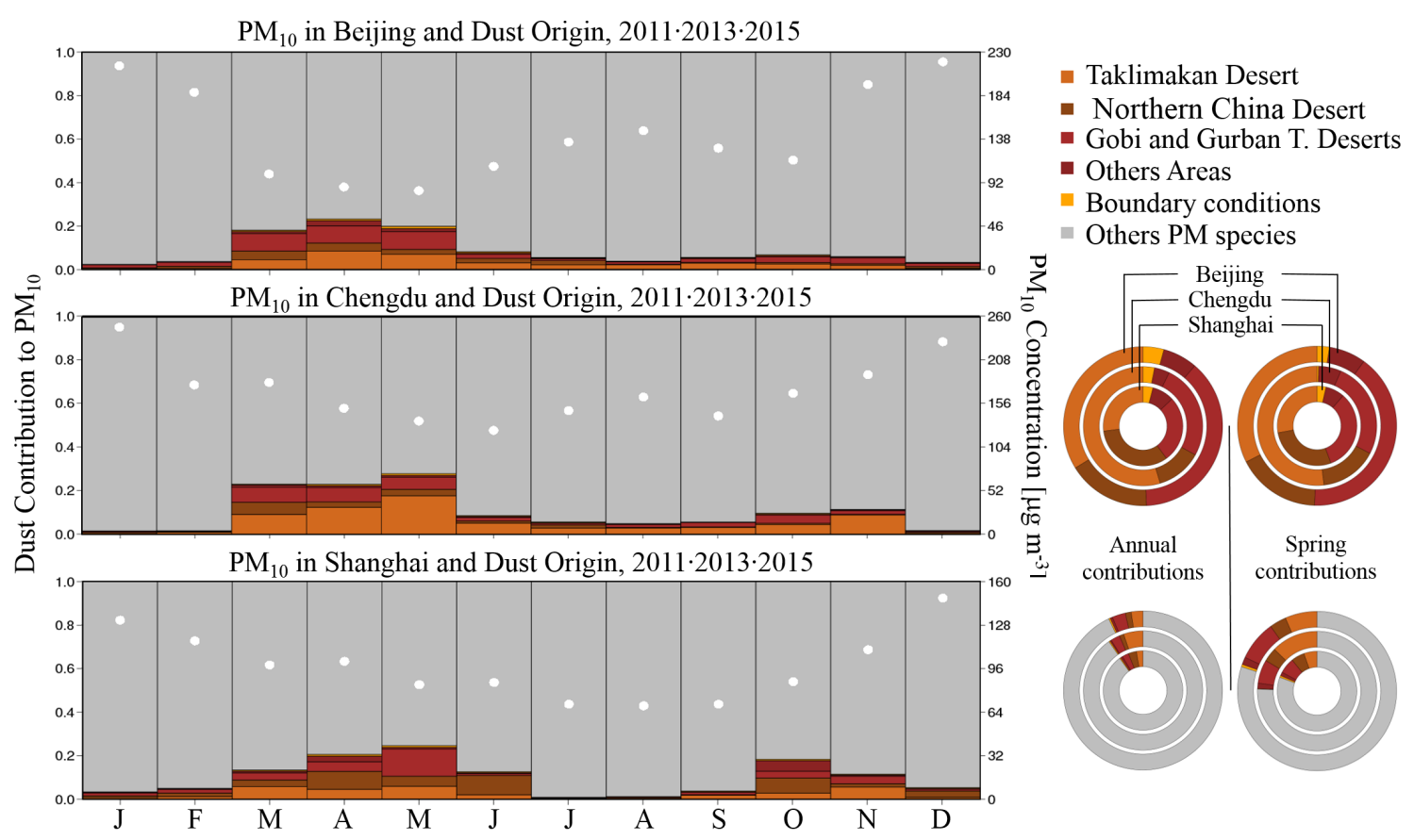

Figure 5. Dust contribution to $\mathrm{PM}_{10}$ pollution in Beijing, Chengdu and Shanghai-Monthly variation calculated from 2011, 2013 and 2015 simulations. Ring plots show annual and spring contributors to $\mathrm{PM}_{10}$ (bottom) and dust origin area (top) for the three cities. White dots variations in monthly $\mathrm{PM}_{10}$ concentrations for the three cities.

It can be observed for the three cities that the highest daily $\mathrm{PM}_{10}$ levels are reached during winter, and the lowest ones during spring (for Beijing) or summer (Shanghai and Chengdu). Amplitudes for these daily values are smaller for Shanghai, ranging from $60 \mu \mathrm{g} \mathrm{m}^{-3}$ to $160 \mu \mathrm{g} \mathrm{m}^{-3}$ than for Beijing and Chengdu, ranging between $90 \mu^{-3} \mathrm{~m}^{-3}$ to $250 \mu \mathrm{g} \mathrm{m}^{-3}$. These values are particularly high compared to 
Chinese National Standard GB 3095-2012 for $\mathrm{PM}_{10}$ in an urban environment, i.e., $24 \mathrm{~h}$ mean: $150 \mu \mathrm{g} \mathrm{m}{ }^{-3}$ and annual mean: $70 \mu \mathrm{g} \mathrm{m}^{-3}$.

Seasonal differences can be explained by meteorological parameters, as winter presents low temperature, low atmospheric dispersion and low rainfall frequencies and on the contrary, summer presents higher temperature, thicker boundary layer and mainly, during monsoon, higher rainfall. Anthropogenic pollutant emissions slightly increase during winter, but not with as much amplitude as PM concentrations.

The mineral dust contribution to $\mathrm{PM}_{10}$ mean computed for 2011, 2013 and 2015 is $6.6 \%, 9.5 \%$ and 9.3\% respectively for Beijing, Chengdu and Shanghai. It can be observed that mineral dust has its highest impact on PM concentrations during spring (with contribution to $\mathrm{PM}_{10}$ for Beijing, Chengdu and Shanghai of $18.9 \%, 24.1 \%$ and $18.3 \%$ respectively). The authors of [73], using source apportionment for spring 2009 calculated a dust contribution to $\mathrm{PM}_{2.5}$ up to $15 \%$ in Chengdu, which is similar to CHIMERE dust contribution to $\mathrm{PM}_{2.5}$, of $12.5 \%$ (and $24.1 \%$ for $\mathrm{PM}_{10}$ ). For all cities, a smaller contribution of dust during fall and almost no contribution during winter and summer were simulated. As little emissions are observed during winter from desert areas ( $5 \%$ of annual total), it was expected to have limited contribution to $\mathrm{PM}_{10}$ for this season. The summer period differs, as even if dust emissions are large, only small impact from dust is observed, as already observed in Figure 4 on the distribution of dust related AOD. Summer in China is a particular season, with high rainfall frequencies over East China, because of monsoon. It is likely that atmospheric aerosols will be deposited because of rainfall, before reaching populated areas. Also, southerly monsoon winds are not prone for advecting dust from western to eastern China.

Also, the Ångström median for spring decreases of $10 \%$ compared to annual Ångström at the Beijing AERONET station, from 1.19 to 1.07, showing a higher contribution of coarse particulate to pollution during spring. On the opposite, we note highest Ångström values (1.27) in winter which indicate a larger contribution to finer particulate matter in the atmospheric column. This result is consistent with CHIMERE simulations, with Ångström equal to 0.91 during spring and Ångström equal to 1.32 for winter.

It can also be observed that dust origins are similar for Shanghai and Beijing, with mineral dust coming from all of the main dust areas in equivalent proportions. Results are different for Chengdu, localized in central China, with more than $50 \%$ of mineral dust coming from Taklimakan, and less impact from Gobi and Northern China deserts than for Beijing and Shanghai. These results show that all considered desert areas have an impact on cities pollution: even if $70 \%$ of dust in our model is emitted from Taklimakan, it will represents less than 30\% of the dust in Shanghai and Beijing, and about $50 \%$ in Chengdu. For these first two cities, the Gobi and Gurban deserts are the largest contributors (about $40 \%$ ).

Dust load in Chinese cities origin has already been investigated, mostly using retro-trajectories [74,75], the use of a tagging method from numerical computing provide an additional way to determine dust origins. Using retro-trajectories, the study [75] estimates for Chengdu's 2013 winter that for 2 days out 90, air pollution is controlled by air masses coming from Xinjiang region (mineral dust from Taklimakan source area ) - a statement similar to the very low contribution found for this season in our results as a consequence of mineral dust low emissions.

\subsubsection{PM Chemical Composition and Comparison to Observations}

Table S2 presents the CHIMERE simulated $\mathrm{PM}_{10}$ composition in Beijing, Chengdu and Shanghai. For the three cities, the main contributor is anthropogenic mineral primary particular $(A M P P)$. Nitrates $\left(\mathrm{NO}_{3(p)}^{-}\right)$are second highest contributor, in Beijing and Shanghai, and 4th in Chengdu. In the three cities, ammonium $\left(\mathrm{NH}_{4(p)}^{+}\right)$contributions are similar, but acid-base balances for nitrates and sulfate $\left(\mathrm{SO}_{4(p)}^{2-}\right)$ are different for Chengdu, compared to Shanghai and Beijing, with more sulfate and acidity in Chengdu. Organic matter $(O M$, includes $P O A$ and $S O A)$ is the third contributor in Beijing and Chengdu, and the fourth contributor in Shanghai to $\mathrm{PM}_{10} . B C$ in the three cities corresponds to around 
$6 \%$ of $\mathrm{PM}_{10}$ pollution. In addition, sea salt presents a little contribution of $3.3 \%$ to Shanghai $\mathrm{PM}_{10}$. It can be noted that evaluating particles components in CHIMERE over China would be of great interest but it is beyond the scope of this paper.

As a consequence, the previous analysis has to be considered as a preliminary semi-quantitative analysis. Here, we will briefly discuss, how our model results correspond to results from observational studies [76-78] even if measurement periods do not exactly correspond. Contributions comparisons are condensed in Table 5 for an easier reading.

Table 5. CHIMERE contribution compared to bibliography.

\begin{tabular}{lccc}
\hline Considered Species & CHIMERE & Reference & City \\
\hline$B C \subset P M_{2.5}$ & $6.4 \%$ & $5 \% ;[76]$ & Beijing \\
$O M \subset P M_{2.5}$ & $16.0 \%$ & $20 \% ;[76]$ & Beijing \\
$N H_{4(p)}^{+} \subset P M_{2.5}$ & $10.5 \%$ & $10 \% ;[76]$ & Beijing \\
$N O_{3(p)}^{-} \subset P M_{2.5}$ & $23.8 \%$ & $15 \% ;[76]$ & Beijing \\
$S O_{4(p)}^{2-} \subset P M_{2.5}$ & $11.2 \%$ & $15 \% ;[76]$ & Beijing \\
$D u s t \subset P M_{2.5}$ & $2.9 \%$ & $7.5 \% ;[76]$ & Beijing \\
\hline$S O_{4(p)}^{2-} \subset P M_{2.5}$ & $21.3 \%$ & $17 \% ;[77]$ & Chengdu \\
$S O_{4(p)}^{2-} \subset P M_{10}$ & $17.5 \%$ & $17 \% ;[77]$ & Chengdu \\
$N O_{3(p)}^{-} \subset P M_{2.5}$ & $12.9 \%$ & $10 \% ;[77]$ & Chengdu \\
$N O_{3(p)}^{-} \subset P M_{10}$ & $10.0 \%$ & $10 \% ;[77]$ & Chengdu \\
\hline$S O_{4(p)}^{2-} \subset P M_{2.5}$ & $14.6 \%$ & $21.7 \% ;[78]$ & Shanghai \\
$N O_{3(p)}^{-} \subset P M_{2.5}$ & $19.6 \%$ & $19.6 \% ;[78]$ & Shanghai \\
$N H_{4(p)}^{+} \subset P M_{2.5}$ & $10.4 \%$ & $12.7 \% ;[78]$ & Shanghai \\
$O M \subset P M_{2.5}$ & $11.1 \%$ & $20.2 \% ;[78]$ & Shanghai \\
\hline
\end{tabular}

The authors of [76] study Beijing's PM $_{2.5}$ annual trends and chemical speciation between 2000 and 2015. Considering 2011, 2013 and 2015 observations, the study presents close results to CHIMERE in Beijing for $\mathrm{PM}_{2.5}$ speciation, with 5\% of $B C$ (against $6.4 \%$ ), $20 \%$ of $O M$ (against $16 \%$ ), $10 \%$ of $\mathrm{NH}_{4(p)}^{+}$ (against $10.5 \%$ ). Results differ slightly between $\mathrm{NO}_{3(p)}^{-} / \mathrm{SO}_{4(p)}^{2-}$ balance, with about $15 \%$ of each in the measures, against $23.8 \% / 11.2 \%$ in CHIMERE. Dust represents $7.5 \%$ of $\mathrm{PM}_{2.5}$ load but is measured as "Soil dust" also includes road and construction dust in addition to mineral desert dust ( $2.9 \%$ in model).

The authors of [77] present Chengdu PM pollution chemical speciation between 2007 and 2013, with its seasonal variability. An increase of $\mathrm{NO}_{3(p)}^{-}$between 2007 and 2013 when a decrease of $S O_{4(p)}^{2-}$ is observed which is also observed in our simulations (2011 to 2015) and better described in [29]. $S O_{4(p)}^{2-}$ abundances for both $\mathrm{PM}_{2.5}$ and $\mathrm{PM}_{10}$ range around $17 \%$ (for 2011 and 2013) which is quite similar to modeled abundances (respectively $21.3 \%$ and $17.4 \%$ ). $\mathrm{NO}_{3(p)}^{-}$contributions for $\mathrm{PM}_{2.5}$ and $\mathrm{PM}_{10}$ range around $10 \%$, when CHIMERE modeled, respectively, $12.9 \%$ and $10.0 \%$. $\mathrm{Al}, \mathrm{Si}$ and $\mathrm{Ca}$ represent together about $20 \%$ of total PM, with maximum contribution in spring, but this does include anthropogenic and natural crustal elements and cannot be directly compared to our modeling results of desert dust.

The authors of [78] sampled Shanghai $\mathrm{PM}_{2.5}$ pollution composition from 2011 to 2013. Results for Shanghai are quite similar to those observed in Beijing, with an underestimation of $S_{4(p)}^{2-}(14.6 \%$ against $21.7 \%)$ and $O M(11.1 \%$ against $20.2 \%)$ but good correspondences for $\mathrm{NO}_{3(p)}^{-}(19.6 \%$ against $19.6 \%)$ and $\mathrm{NH}_{4(p)}^{+}(10.4 \%$ against $12.7 \%)$.

\subsubsection{Daily Variability of $\mathrm{PM}_{10}$ Component Concentrations}

$\mathrm{PM}_{10}$ components daily concentration distributions for Beijing, Chengdu and Shanghai are displayed in Figure 6. Median values for dust concentrations correspond to few micrograms only, in the three cities, which rank it as one of lowest contributors to $\mathrm{PM}_{10}$ pollution in our simulations, as it 
has been also observed in Table S2, with mean concentration contributions. The additional information provided in the Figure 6 is the daily variability of each component, and it appears that dust presents the largest variability and in the three cities, the highest daily concentration among $\mathrm{PM}_{10}$ components is due to dust (i.e., reaching $400 \mu \mathrm{g} \mathrm{m}^{-3}, 540 \mu \mathrm{g} \mathrm{m}^{-3}$ and $350 \mathrm{\mu g} \mathrm{m}^{-3}$ respectively for Beijing, Chengdu and Shanghai). This particular aspect follows dust emissions dynamics, very localized in time (q.v. Table 1, 5th column), and responsible of very strong pollution events. Thus, it is judicious to focus on dust contribution to PM pollution events in cities rather than the average impact of dust, and this is the key point of our work, exploiting the most original CHIMERE model abilities.

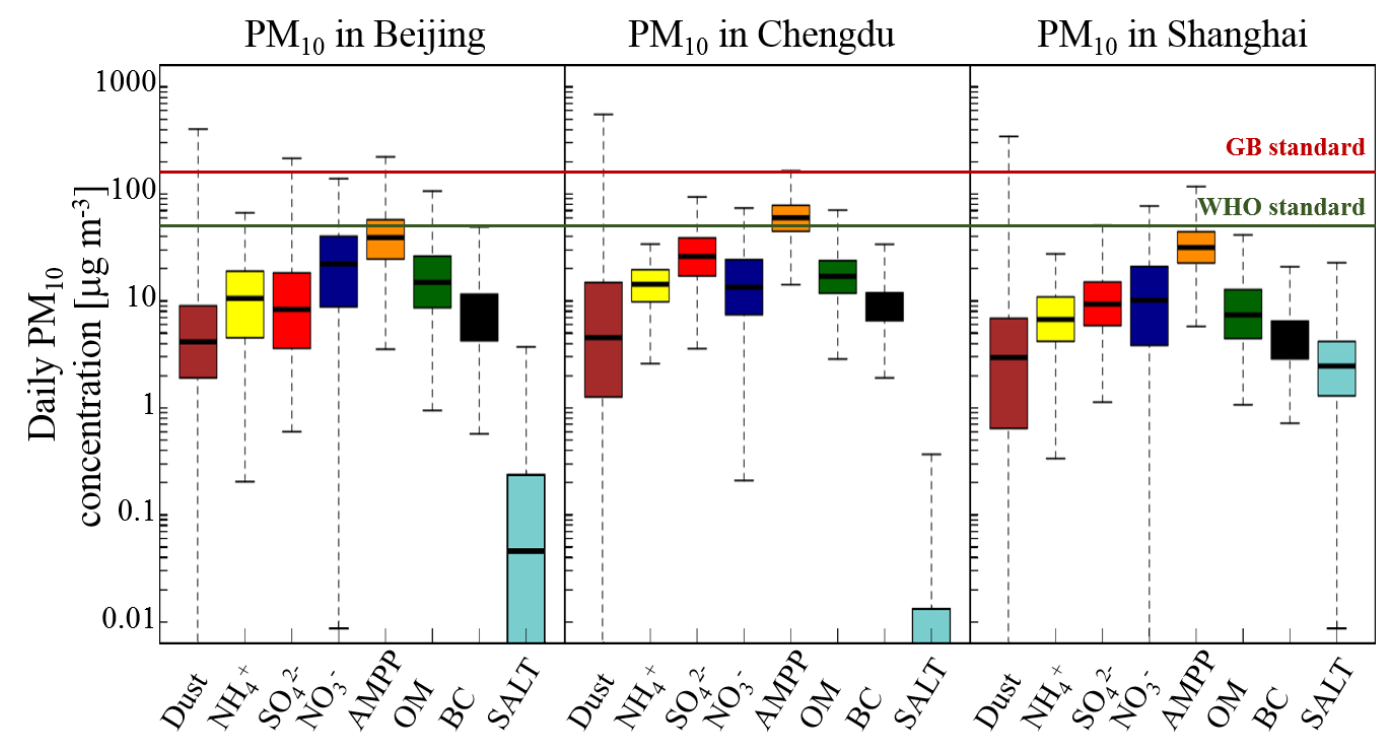

Chemical contributants

Figure 6. Boxplot distribution for simulated daily concentrations (1095 days considered) of species contributing to $\mathrm{PM}_{10}$. (left) Beijing (center) Chengdu and (right) Shanghai. Model species correspond to: Dust (only representing the desert and natural fraction), $\mathrm{NH}_{4(p)}^{+}$(ammonium), $\mathrm{SO}_{4}^{2-}$ (sulfate), $\mathrm{NO}_{3(p)}^{-}$(nitrate), AMPP (Anthropogenic Mineral Primary Particulate matter-including soil dust emitted from anthropogenic activities such as construction), OM (primary and secondary Organic Matter, BC (Black Carbon), from biogenic and anthropogenic sources) and SALT (sea salt). Chinese and WHO standards for daily $\mathrm{PM}_{10}$ have been added to evaluate the frequency of overshoot for each species.

\subsubsection{Dust Contribution during High Pollution Episodes}

From Figure 7 and also Table 6 it can be observed for the whole period, that mineral dust is a minor contributor to $\mathrm{PM}_{10}$ and even more to $\mathrm{PM}_{2.5}$ concentrations. For instance, for most of the days (between $70 \%$ to $75 \%$ ) for the three cities, the dust contribution to $\mathrm{PM}_{10}$ is below $10 \%$ (Figure 7), only for $7.2 \%$ to $11.0 \%$ of days, dust it is more than $25 \%$. When studying the $25 \%$ most strongly polluted days, dust have slightly larger contributions for Chengdu and Shanghai, but not for Beijing. For the first two cities, this means that the dust presence is correlated with pollution events, although it is generally not dominant. On the contrary, for Beijing, PM pollution events occur during winter due to anthropogenic sources, and dust has only little impact on air pollution for this season. 


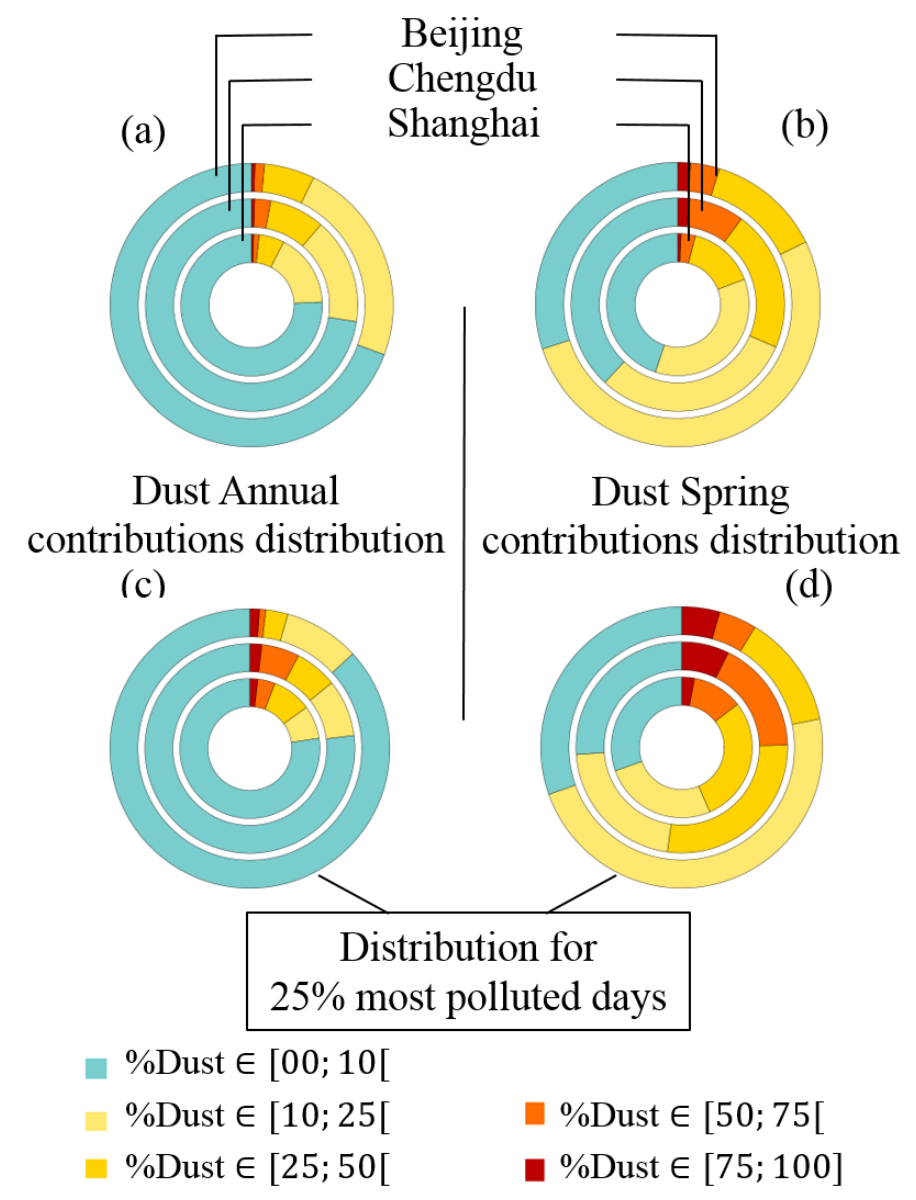

Figure 7. (a) Percentage of days when dust contributes between 0-10\%, 10-25\%, 25-50\%, 50-75\% and $75-100 \%$ to daily $\mathrm{PM}_{10}$ averages; (b) same as (a), but for spring only; (c) Same as (a), but for the $25 \%$ of most polluted days only (in terms of $\mathrm{PM}_{10}$ level); (d) Same as for (c), but for spring only.

If we focus now on spring season, we can identify a larger impact from mineral dust to cities PM pollution, an impact which gets even stronger when selecting the $25 \%$ most polluted $\mathrm{PM}_{10}$ days. During spring, $\mathrm{PM}_{10}$ pollution events can frequently be affected by dust in addition to anthropogenic PM pollution sources: the dust contribution is higher than $25 \%$ for $22 \%$ of days for Beijing, as much as $52 \%$ for Chengdu and $43 \%$ for Shanghai. To a lesser extent, mineral dust is implied to $\mathrm{PM}_{2.5}$ events (Fraction of 9\% for Beijing, 19\% for Chengdu and 14\% for Shanghai).

Additional information from the AERONET station located in Beijing (see Figure S3 in supplements) shows that the fraction of days with Ångström coefficients below 0.4 (which characterizes a dominant dust contribution to the PM column) is nearly a factor of 2 larger for spring than for the rest of the year. The same increase is observed from simulated Ångström coefficients. In addition, for the $25 \%$ of days with the largest AOD values, the Beijing AERONET station shows a larger fraction of days with an Ångström coefficient below 0.4:0.04 for all seasons, and 0.08 for spring only. These values are somewhat higher than in CHIMERE (respectively 0.02 and 0.06). As a conclusion, also for AOD, the dust contribution is for most of the days not dominant. 
Table 6. Fraction of days when the dust contributions to daily $\mathrm{PM}_{2.5}$ or $\mathrm{PM}_{10}$ are at least $25 \%$. These values were calculated for Beijing, Chengdu and Shanghai, and for various samples: all days in 2011, 2013 and 2015, only for the spring season, for days with the largest pollution (in terms of $\mathrm{PM}_{2.5}$ and $\mathrm{PM}_{10}$ respectively), for these latter days, but only during spring. As an example the table reads as follows: For Chengdu, during the 25\% most polluted days in spring 2011, 2013 and 2015, 52\% of days displayed dust contributions larger than $25 \%$. $P_{75, Y e a r} / P_{75, \text { Spring }}$ indicates the $\mathrm{PM}_{10} 75$ th percentiles value. They are threshold values, above which a day is considered as one of the $25 \%$ most polluted days. pol. days stands for "polluted days", with $\left[P M_{x}\right]>P_{75, P M_{x}}$. F.o.d stands for "Fraction of days".

\begin{tabular}{|c|c|c|c|c|}
\hline $\begin{array}{l}\text { Cities and } \\
\text { Species }\end{array}$ & $\begin{array}{l}\text { Days Year }{ }^{-1} / \\
\text { Days Spring } \\
\text { with Dust } \\
\text { contrib. }>\mathbf{2 5 \%}\end{array}$ & $\begin{array}{l}\text { (Year/Spring) } \\
\text { F.o.d with Dust } \\
\text { contrib. }>25 \%\end{array}$ & $\begin{array}{l}P_{75, \text { Year }} / \\
P_{75, \text { Spring }} \\
\left(\mu \mathrm{g} \mathrm{m}^{-3}\right)\end{array}$ & $\begin{array}{c}\text { (Year/Spring) pol.days } \\
\text { F.o.d with Dust } \\
\text { contrib. }>25 \%\end{array}$ \\
\hline Beijing $\mathrm{PM}_{2.5}$ & $7.3 / 7.3$ & $0.02 / 0.08$ & $144 / 97$ & $0.02 / 0.09$ \\
\hline Beijing $\mathrm{PM}_{10}$ & $25.5 / 16.4$ & $0.07 / 0.18$ & $185 / 123$ & $0.04 / 0.22$ \\
\hline Chengdu $\mathbf{P M}_{2.5}$ & $14.6 / 10.1$ & $0.04 / 0.11$ & $150 / 128$ & $0.05 / 0.19$ \\
\hline Chengdu $\mathbf{P M}_{10}$ & $40.1 / 28.3$ & $0.11 / 0.31$ & $206 / 183$ & $0.14 / 0.52$ \\
\hline Shanghai $\mathbf{P M}_{2.5}$ & $10.9 / 04.5$ & $0.03 / 0.05$ & $94 / 84$ & $0.06 / 0.14$ \\
\hline Shanghai $\mathbf{P M}_{10}$ & $29.2 / 17.3$ & $0.08 / 0.19$ & $122 / 112$ & $0.15 / 0.43$ \\
\hline
\end{tabular}

\section{Conclusions}

In this study, we aimed at evaluating the impact of mineral dust on air quality in three Chinese megacities with the regional CHIMERE CTM. Modeled dust emissions average $283 \mathrm{Mt} \mathrm{year}^{-1}$, with about 70\% emitted from Taklimakan area, 23\% emitted from the Gobi desert and 6.5\% emitted from Northern China desert. MODIS information was used to validate correspondences between CHIMERE AOD and satellite AOD variation, and results appeared to be satisfying, which allows us to then study the dust contribution to cities' air pollution. It has been chosen to focus on Beijing, Chengdu and Shanghai, because of their large population and different geographical locations with respect to emission zones. We have estimated the impact of dust on cities' air pollution: we found average contributions of $10 \mu \mathrm{g} \mathrm{m}^{-3}(6.6 \%), 17 \mu \mathrm{g} \mathrm{m}^{-3}(9.5 \%)$ and $9 \mu \mathrm{g} \mathrm{m}^{-3}(9.3 \%)$ to $\mathrm{PM}_{10}$ in Beijing, Chengdu and Shanghai respectively. These values values must be taken into account while evaluating Chinese cities air quality, as they represent a significant burden for the cities air quality in regards to the annual WHO threshold of $20 \mu \mathrm{g} \mathrm{m}^{-3}$. The dust contribution is highly seasonally dependent, with highest contributions during spring, when contributions to $\mathrm{PM}_{10}$ reach $22 \mu \mathrm{g} \mathrm{m}^{-3}(18.9 \%)$, $37.0 \mu \mathrm{g} \mathrm{m}^{-3}(24.1 \%)$ and $12 \mu \mathrm{g} \mathrm{m}^{-3}(18.3 \%)$. In Beijing and Shanghai, dust is advected rather equally from all main Chinese deserts, while in Chengdu, it originates mainly from the Taklimakan desert. Analysis for days with enhanced $\mathrm{PM}_{10}$ pollution (above the 75th percentile) especially in the spring season shows that dust is often a main contributor (dust contribution larger than $25 \%$ ) during $\mathrm{PM}_{10}$ polluted days especially in the spring season: this holds at $22 \%$ of the days for Beijing, $52 \%$ for Chengdu and $43 \%$ for Shanghai. Considering all seasons, the impact on polluted events is smaller, especially during winter, when particulate matter pollution mostly originates from anthropogenic sources. Finally, if mineral dust do not represent a predominant source compared to anthropogenic pollutant on average, mineral dust alone leads to an exceedance of the daily WHO threshold for $\mathrm{PM}_{10}\left(50 \mu \mathrm{g} \mathrm{m}^{-3}\right)$ in Bejing for 10 days per year, 29 days per year in Chengdu and 13 days per year in Shanghai.

In the future, dust vertical transport modeling should be investigated more deeply and compared to products which contains information on vertical dispersion (CALIOP [69], AEROIASI [59]). In addition, updated emissions inventories should be used and $S O A$ modeling should be improved 
Supplementary Materials: The following are available at http://www.mdpi.com/2073-4433/11/7/708/s1: Figure S1: $550 \mathrm{~nm}$ AOD spatial distribution to $1^{\circ} \times 1^{\circ}$ resolution for 2011, 2013 and 2015. Table S1: Spatial correspondences between MODIS $550 \mathrm{~nm}$ AOD and CHIMERE $550 \mathrm{~nm}$ AOD. Table S2: CHIMERE Model PM 10 annual composition for Bejing, Chengdu and Shanghai. Figure S2: Daily $\mathrm{PM}_{2.5}$ time series for monitoring stations and CHIMERE simulations. Figure S3: Daily Ångström coefficient distribution at Beijing station. Figure S4: PM $_{10}$ simulated surface concentration. Figure S5: PM station locations.

Author Contributions: M.L., G.F. and M.B. designed the experiments and M.L. carried them out. G.S. prepared meteorological and emission data. F.M. and W.T. provided data surface measurements from CRAES institution. M.L. adapted the model code and performed the simulations. B.L. developed the database of surface characteristics for Asian deserts. Q.Z., J.C. and G.D. help to the analysis. M.L. prepared the manuscript and all authors contributed to the text, interpretation of the results and reviewed the manuscript. All authors have read and agreed to the published version of the manuscript.

Funding: M. Lachatre was funded by the Sorbonne Université, 1'Ecole Doctorale des Sciences de l'Environnement d'Ile de France (ED129) and PolEASIA ANR project under the allocation ANR-15-CE04-0005.

Acknowledgments: This work was granted access to the HPC resources of TGCC under the allocation A0030107232 made by GENCI. We acknowledge the free use of MODIS AOD data from the Terra from (https:/ / terra.nasa.gov/, last consulted 25/09/2018). Surface measurements provided by U.S. Department of State Air Quality Monitoring Program, Mission China (www.stateair.net, last consulted 07/10/2018). We also acknowledge the Chinese Research Academy of Environmental Sciences (CRAES) in Beijing, for providing us $\mathrm{PM}_{2.5}$ and $\mathrm{PM}_{10}$ surface concentrations data. We also acknowledge the NASA's AERONET network. The development and production of AEROIASI retrievals are supported by the Centre National des Études Spatiales (CNES, the French Space Agency, IASI project/Terre, Océan, Surfaces continentales, Atmosphère) and the Programme National de Télédétection Spatiale (PNTS, http:/ / programmes.insu.cnrs.fr/pnts, grant $\mathrm{n}^{\mathrm{O}}$ PNTS-2013-05, project "SYNAEROZON"). IASI is a joint mission of EUMETSAT and CNES.

Conflicts of Interest: The authors declare no conflict of interest.

\section{References}

1. Geng, G.; Zhang, Q.; Martin, R.V.; van Donkelaar, A.; Huo, H.; Che, H.; Lin, J.; He, K. Estimating long-term $\mathrm{PM}_{2.5}$ concentrations in China using satellite-based aerosol optical depth and a chemical transport model. Remote Sens. Environ. 2015, 166, 262-270. [CrossRef]

2. Huang, R.J.; Zhang, Y.; Bozzetti, C.; Ho, K.F.; Cao, J.J.; Han, Y.; Daellenbach, K.R.; Slowik, J.G.; Platt, S.M.; Canonaco, F.; et al. High secondary aerosol contribution to particulate pollution during haze events in China. Nature 2014, 514, 2018-222. [CrossRef] [PubMed]

3. Liu, Z.; Gao, W.; Yu, Y.; Hu, B.; Xin, J.; Sun, Y.; Wang, L.; Wang, G.; Bi, X.; Zhang, G.; et al. Characteristics of $\mathrm{PM}_{2.5}$ mass concentrations and chemical species in urban and background areas of China: Emerging results from the CARE-China network. Atmos. Chem. Phys. 2018, 18, 8849-8871. [CrossRef]

4. Kaiser, D.P.; Qian, Y. Decreasing trends in sunshine duration over China for 1954-1998: Indication of increased haze pollution? Geophys. Res. Lett. 2002, 29, 38-1-38-4, [CrossRef]

5. Xie, R.; Sabel, C.E.; Lu, X.; Zhu, W.; Kan, H.; Nielsen, C.P.; Wang, H. Long-term trend and spatial pattern of PM 2.5 induced premature mortality in China. Environ. Int. 2016, 97, 180-186. [CrossRef]

6. Wang, Y.; Teter, J.; Sperling, D. China's soaring vehicle population: Even greater than forecasted? Energy Policy 2011, 39, 3296-3306. [CrossRef]

7. Liu, J.; Niu, D.; Song, X. The energy supply and demand pattern of China: A review of evolution and sustainable development. Renew. Sustain. Energy Rev. 2013, 25, 220-228. [CrossRef]

8. Ma, Z.; Hu, X.; Sayer, A.; Levy, R.; Zhang, Q.; Xue, Y.; Tong, S.; Bi, J.; Huang, L.; Liu, Y. Satellite-Based Spatiotemporal Trends in PM2.5 Concentrations: China, 2004-2013. Environ. Health Perspect. 2016, 124, 184-192. [CrossRef]

9. Liu, F.; Beirle, S.; Zhang, Q.; Van Der A, R.J.; Zheng, B.; Tong, D.; He, K. NOxemission trends over Chinese cities estimated from OMI observations during 2005 to 2015. Atmos. Chem. Phys. 2017, 17, 9261-9275. [CrossRef]

10. IPCC. Climate Change 2001: The Scientific Basis. Contribution of Working Group I to the Third Assessment Report of theIntergovernmental Panel on Climate Change; Houghton, J.T., Ding, Y., Griggs, D.J., Noguer, M., van der Linden, P.J., Dai, X., Maskell, K., Johnson, C.A., Eds.; Cambridge University Press: Cambridge, UK; New York, NY, USA, 2011; 881p. 
11. Huneeus, N.; Schulz, M.; Balkanski, Y.; Griesfeller, J.; Prospero, J.; Kinne, S.; Bauer, S.; Boucher, O.; Chin, M.; Dentener, F.; et al. Global dust model intercomparison in AeroCom phase I. Atmos. Chem. Phys. 2011, 11, 7781-7816. [CrossRef]

12. Hamilton, D.S.; Scanza, R.A.; Feng, Y.; Guinness, J.; Kok, J.F.; Li, L.; Liu, X.; Rathod, S.D.; Wan, J.S.; $\mathrm{Wu}, \mathrm{M}$; et al. Improved methodologies for Earth system modelling of atmospheric soluble iron and observation comparisons using the Mechanism of Intermediate complexity for Modelling Iron (MIMI v1.0). Geosci. Model Dev. 2019, 12, 3835-3862. [CrossRef]

13. Sokolik, I.N.; Toon, O.B. Incorporation of mineralogical composition into models of the radiative properties of mineral aerosol from UV to IR wavelengths. J. Geophys. Res. Atmos. 1999, 104, 9423-9444, [CrossRef]

14. Li, L.; Sokolik, I.N. The Dust Direct Radiative Impact and Its Sensitivity to the Land Surface State and Key Minerals in the WRF-Chem-DuMo Model: A Case Study of Dust Storms in Central Asia. J. Geophys. Res. Atmos. 2018, 123, 4564-4582, [CrossRef]

15. Laurent, B.; Marticorena, B.; Bergametti, G.; Mei, F. Modeling mineral dust emissions from Chinese and Mongolian deserts. Glob. Planet. Chang. 2006, 52, 121-141. [CrossRef]

16. Gong, S.L.; Zhang, X.Y.; Zhao, T.L.; McKendry, I.G.; Jaffe, D.A.; Lu, N.M. Characterization of soil dust aerosol in China and its transport and distribution during 2001 ACE-Asia: 2. Model simulation and validation. J. Geophys. Res. Atmos. 2003, 108, [CrossRef]

17. Ginoux, P.; Chin, M.; Tegen, I.; Prospero, J.M.; Holben, B.; Dubovik, O.; Lin, S. Sources and distributions of dust aerosols simulated with the GOCART model. J. Geophys. Res. Atmos. 2001, 106, 255-273. [CrossRef]

18. Mahowald, N.; Kohfeld, K.; Hansson, M.; Balkanski, Y.; Harrison, S.P.; Prentice, I.C.; Schulz, M.; Rodhe, H. Dust sources and deposition during the last glacial maximum and current climate: A comparison of model results with paleodata from ice cores and marine sediments. J. Geophys. Res. Atmos. 1999. [CrossRef]

19. Yang, F.; Ye, B.; He, K.; Ma, Y.; Cadle, S.H.; Chan, T.; Mulawa, P.A. Characterization of atmospheric mineral components of $\mathrm{PM}_{2.5}$ in Beijing and Shanghai , China. Sci. Total Environ. 2005, 343, 221-230. [CrossRef]

20. Pan, X.; Uno, I.; Zhe, W.; Nishizawa, T.; Sugimoto, N.; Yamamoto, S.; Kobayashi, H.; Sun, Y.; Fu, P.; Tang, X.; et al. Real-time observational evidence of changing Asian dustmorphology with the mixing of heavy anthropogenic pollution. Sci. Rep. 2017, 7, 335.-017-00444-w. [CrossRef]

21. Yu, Y.; Kalashnikova, O.V.; Garay, M.J.; Notaro, M. Climatology of Asian dust activation and transport potential based on MISR satellite observations and trajectory analysis. Atmos. Chem. Phys. 2019, 19, 363-378. [CrossRef]

22. Yang, F.; Tan, J.; Zhao, Q.; Du, Z.; He, K.; Ma, Y.; Duan, F.; Chen, G.; Zhao, Q. Characteristics of $\mathrm{PM}_{2.5}$ speciation in representative megacities and across China. Atmos. Chem. Phys. 2011, 11, 5207-5219. [CrossRef]

23. Menut, L.; Bessagnet, B.; Khvorostyanov, D.; Beekmann, M.; Blond, N.; Colette, a.; Coll, I.; Curci, G.; Foret, G.; Hodzic, A.; et al. CHIMERE 2013: A model for regional atmospheric composition modelling. Geosci. Model Dev. 2013, 6, 981-1028. [CrossRef]

24. Mailler, S.; Menut, L.; Khvorostyanov, D.; Valari, M.; Couvidat, F.; Siour, G.; Turquety, S.; Briant, R.; Tuccella, P.; Bessagnet, B.; et al. CHIMERE-2017: From urban to hemispheric chemistry-transport modeling. Geosci. Model Dev. 2017, 10, 2397-2423. [CrossRef]

25. Van Leer, B. Towards the ultimate conservative difference scheme. IV. A new approach to numerical convection. J. Comput. Phys. 1977, 23, 276-299. [CrossRef]

26. Owens, R.G.; Hewson, T. ECMWF Forecast User Guide; ECMWF: Reading, UK, 2018. [CrossRef]

27. Olivier, W.; Xin, Z.; Michael, J.P. Fast-J: Accurate Simulation of In- and Below-Cloud Photolysis in Tropospheric Chemical Models. J. Atmos. Chem. 2000.:1006415919030. [CrossRef]

28. Janssens-Maenhout, G.; Crippa, M.; Guizzardi, D.; Dentener, F.; Muntean, M.; Pouliot, G.; Keating, T.; Zhang, Q.; Kurokawa, J.; Wankmüller, R.; et al. HTAP-v2.2: A mosaic of regional and global emission grid maps for 2008 and 2010 to study hemispheric transport of air pollution. Atmos. Chem. Phys. 2015, 15, 11411-11432. [CrossRef]

29. Lachatre, M.; Fortems-Cheiney, A.; Foret, G.; Siour, G.; Dufour, G.; Clarisse, L.; Clerbaux, C.; Coheur, P.F.; Van Damme, M.; Beekmann, M. The unintended consequence of $\mathrm{SO}_{2}$ and $\mathrm{NO}_{2}$ regulations over China: Increase of ammonia levels and impact on $\mathrm{PM}_{2.5}$ concentrations. Atmos. Chem. Phys. 2019, 19, 6701-6716. [CrossRef] 
30. Zheng, B.; Tong, D.; Li, M.; Liu, F.; Hong, C.; Geng, G.; Li, H.; Li, X. Trends in China's anthropogenic emissions since 2010 as the consequence of clean air actions. Atmos. Chem. Phys. 2018, 18, 14095-14111. [CrossRef]

31. Guenther, A.B.; Jiang, X.; Heald, C.L.; Sakulyanontvittaya, T.; Duhl, T.; Emmons, L.K.; Wang, X. Model Development The Model of Emissions of Gases and Aerosols from Nature version 2.1 (MEGAN2.1): An extended and updated framework for modeling biogenic emissions. Geosci. Model Dev. 2012, 1471-1492. [CrossRef]

32. Hauglustaine, D.A.; Hourdin, F.; Jourdain, L.; Filiberti, M.A.; Walters, S.; Lamarque, J.F.; Holland, E.A. Interactive chemistry in the Laboratoire de Météorologie Dynamique general circulation model: Description and background tropospheric chemistry evaluation. J. Geophys. Res. Atmos. 2004, 109. [CrossRef]

33. Hourdin, F.; Musat, I.; Bony, S.; Braconnot, P.; Codron, F.; Dufresne, J.L.; Fairhead, L.; Filiberti, M.A.; Friedlingstein, P.; Grandpeix, J.Y.; et al. The LMDZ4 general circulation model: Climate performance and sensitivity to parametrized physics with emphasis on tropical convection. Clim. Dyn. 2006, 27, 787-813. [CrossRef]

34. Nenes, A.; Pilinis, C.; Pandis, S. ISORROPIA: A new thermodynamic model for inorganic multicomponent atmospheric aerosols. Aquatic. Geochem. 1998, 4, 123-152. [CrossRef]

35. Derognat, C.; Beekmann, M.; Baeumle, M.; Martin, D.; Schmidt, H. Effect of biogenic volatile organic compound emissions on tropospheric chemistry during the Atmospheric Pollution Over the Paris Area (ESQUIF) campaign in the Ile-de-France region. J. Geophys. Res. Atmos. 2003, 108. [CrossRef]

36. Pankow, J.F. An absorption model of gas/particle partitioning of organic compounds in the atmosphere. Atmos. Environ. 1994, 28, 185-188. [CrossRef]

37. Kaupp, H.; Umlauf, G. Atmospheric gas-particle partitioning of organic compounds: Comparison of sampling methodS. Atmos. Environ. 1992, 26, 2259-2267. [CrossRef]

38. Ma, S.; Zhang, X.; Gao, C.; Tong, D.Q.; Xiu, A.; Wu, G.; Cao, X.; Huang, L.; Zhao, H.; Zhang, S.; et al. Multimodel simulations of a springtime dust storm over northeastern China: Implications of an evaluation of four commonly used air quality models (CMAQ v5.2.1, CAMx v6.50, CHIMERE v2017r4, and WRF-Chem v3.9.1). Geosci. Model Dev. 2019, 12, 4603-4625. [CrossRef]

39. Laurent, B.; Marticorena, B.; Bergametti, G. Simulation of the mineral dust emission frequencies from desert areas of China and Mongolia using an aerodynamic roughness length map derived from the POLDER/ADEOS 1 surface products. J. Geophys. Res. Atmos. 2005, 110, 1-21. [CrossRef]

40. Menut, L.; Schmechtig, C.; Marticorena, B. Sensitivity of the Sandblasting Flux Calculations to the Soil Size Distribution Accuracy. J. Atmos. Ocean. Technol. 2005, 22, 1875-1884. [CrossRef]

41. Alfaro, S.; Gomes, L. Modeling mineral aerosol production by wind erosion: Emission intensities and aerosol size distributions in source areas. J. Geophys. Res. Atmos. 2001, 106, 18075-18084. [CrossRef]

42. Shao, Y. A model for mineral dust emission. J. Geophys. Res. Atmos. 2001, 106, 20239-20254. [CrossRef]

43. Kok, J.F. A scaling theory for the size distribution of emitted dust aerosols suggests climate models underestimate the size of the global dust cycle. Proc. Natl. Acad. Sci. USA 2011, 108, 1016-1021. [CrossRef] [PubMed]

44. Albani, S.; Mahowald, N.M.; Perry, A.T.; Scanza, R.A.; Zender, C.S.; Heavens, N.G.; Maggi, V.; Kok, J.F.; Otto-Bliesner, B.L. Improved dust representation in the Community Atmosphere Model. J. Adv. Model. Earth Syst. 2014, 6, 541-570. [CrossRef]

45. Alfaro, S.; Gaudichet, A.; Gomes, L.; Maillé, M. Modeling the size distribution of soil aerosol product by sandblasting. J. Geophys. Res. Atmos. 1997, 102, 11239-11249. [CrossRef]

46. Mahowald, N.M.; Muhs, D.R.; Levis, S.; Rasch, P.J.; Yoshioka, M.; Zender, C.S.; Luo, C. Change in atmospheric mineral aerosols in response to climate: Last glacial period, preindustrial, modern, and doubled carbon dioxide climates. J. Geophys. Res. Atmos. 2006, 111. [CrossRef]

47. Mahowald, N.; Albani, S.; Kok, J.F.; Engelstaeder, S.; Scanza, R.; Ward, D.S.; Flanner, M.G. The size distribution of desert dust aerosols and its impact on the Earth system. Aeolian Res. 2014, 15, 53-71. [CrossRef]

48. Kok, J.F.; Mahowald, N.M.; Fratini, G.; Gillies, J.A.; Ishizuka, M.; Leys, J.F.; Mikami, M.; Park, M.S.; Park, S.U.; Van Pelt, R.S.; et al. An improved dust emission model-Part 1: Model description and comparison against measurements. Atmos. Chem. Phys. 2014, 14, 13023-13041. [CrossRef] 
49. Foret, G.; Bergametti, G.; Dulac, F.; Menut, L. An optimized particle size bin scheme for modeling mineral dust aerosol. J. Geophys. Res. Atmos. 2006, 111. [CrossRef]

50. Wang, G.H.; Cheng, C.L.; Huang, Y.; Tao, J.; Ren, Y.Q.; Wu, F.; Meng, J.J.; Li, J.J.; Cheng, Y.T.; Cao, J.J.; et al. Evolution of aerosol chemistry in Xi'an, inland China, during the dust storm period of 2013-Part 1: Sources, chemical forms and formation mechanisms of nitrate and sulfate. Atmos. Chem. Phys. 2014, 14, 11571-11585. [CrossRef]

51. Fu, X.; Wang, S.X.; Cheng, Z.; Xing, J.; Zhao, B.; Wang, J.D.; Hao, J.M. Source, transport and impacts of a heavy dust event in the Yangtze River Delta, China, in 2011. Atmos. Chem. Phys. 2014, 14, 1239-1254. [CrossRef]

52. Filonchyk, M.; Yan, H.; Zhang, Z.; Yang, S.; Li, W.; Li, Y. Author Correction: Combined use of satellite and surface observations to study aerosol optical depth in different regions of China. Sci. Rep. 2019, 9, 1-15. [CrossRef]

53. Wang, X.; Liu, J.; Che, H.; Ji, F.; Liu, J. Spatial and temporal evolution of natural and anthropogenic dust events over northern China. Sci. Rep. 2018, 8, 1-9. [CrossRef] [PubMed]

54. Seinfeld, J.H.; Pandis, S.N. Atmospheric from Air Pollution to Climate Change, 2nd ed.; Wiley-Interscience: Hoboken, NJ, USA, 2006; pp. 628-674.

55. Zhang, L.; Gong, S.; Padro, J.; Barrie, L. A size-segregated particle dry deposition scheme for an atmospheric aerosol module. Atmos. Environ. 2001, 35, 549-560. [CrossRef]

56. Zhang, Q.; Laurent, B.; Velay-Lasry, F.; Ngo, R.; Derognat, C.; Marticorena, B.; Albergel, A. An air quality forecasting system in Beijing-Application to the study of dust storm events in China in May 2008. J. Environ. Sci. 2012, 24, 102-111. [CrossRef]

57. Di Biagio, C.; Formenti, P.; Balkanski, Y.; Caponi, L.; Cazaunau, M.; Pangui, E.; Journet, E.; Nowak, S.; Caquineau, S.; Andreae, M.O.; et al. Global scale variability of the mineral dust long-wave refractive index: A new dataset of in situ measurements for climate modeling and remote sensing. Atmos. Chem. Phys. 2017, 17, 1901-1929. [CrossRef]

58. Cuesta, J.; Eremenko, M.; Flamant, C.; Dufou, G.; Laurent, B.; Bergametta, G.; Höpfner, M.; Orphal, J.; Zhou, D. Three-dimensional distribution of a major desert dust outbreak over East Asia in March 2008 derived from IASI satellite observations Juan. J. Geophys. Res. Atmos. 2015, 7099-7127. [CrossRef]

59. Cuesta, J.; Flamant, C.; Gaetani, M.; Knippertz, P.; Fink, A.H.; Chazette, P.; Eremenko, M.; Dufour, G.; Di Biagio, C.; Formenti, P. Three-dimensional pathways of dust over the Sahara during summertime 2011 as revealed by new IASI observations. Q. J. R. Meteorol. Soc. 2020. [CrossRef]

60. Eck, T.F.; Holben, B.N.; Reid, J.S.; Dubovik, O.; Smirnov, A.; O’Neill, N.T.; Slutsker, I.; Kinne, S. Wavelength dependence of the optical depth of biomass burning, urban, and desert dust aerosols. J. Geophys. Res. Atmos. 1999, 104, 31333-31349. [CrossRef]

61. Weilin, W.; Suli, Z.; Limin, J.; Michael, T.; Boen, Z.; Gang, X.; Haobo, H. Estimation of PM2.5 Concentrations in China Using a Spatial Back Propagation Neural Network. Sci. Rep. 2019. [CrossRef]

62. Flemming, J.; Stern, R.; Yamartino, R.J. A new air quality regime classification scheme for $\mathrm{O}_{3}, \mathrm{NO}_{2}, \mathrm{SO}_{2}$ and $\mathrm{PM}_{10}$ observations sites. Atmos. Environ. 2005, 39, 6121-6129. [CrossRef]

63. Martini, F.M.S.; Hasenkopf, C.A.; Roberts, D.C. Statistical analysis of PM2.5 observations from diplomatic facilities in China. Atmos. Environ. 2015, 110, 174-185. [CrossRef]

64. Tan, S.C.; Li, J.; Che, H.; Chen, B.; Wang, H. Transport of East Asian dust storms to the marginal seas of China and the southern North Pacific in spring 2010. Atmos. Environ. 2017, 148, 316-328. [CrossRef]

65. Chen, S.; Huang, J.; Qian, Y.; Zhao, C.; Kang, L.; Yang, B.; Wang, Y.; Liu, Y.; Yuan, T.; Wang, T.; et al. An Overview of Mineral Dust Modeling over East Asia. J. Meteorol. Res. 2017, 31, 633-653. [CrossRef]

66. Hou, Z.J.Z. A Simulated Climatology of Asian Dust Aerosol and Its Trans-Pacific Transport. Part I: Mean Climate and Validation. J. Clim. 2006, 19, 88-104.

67. Proestakis, E.; Amiridis, V.; Marinou, E.; Georgoulias, A.K.; Solomos, S.; Kazadzis, S.; Chimot, J.; Che, H.; Alexandri, G.; Binietoglou, I.; et al. Nine-year spatial and temporal evolution of desert dust aerosols over South and East Asia as revealed by CALIOP. Atmos. Chem. Phys. 2018, 18, 1337-1362. [CrossRef]

68. Ansmann, A.; Bösenberg, J.; Chaikovsky, A.; Comerón, A.; Eckhardt, S.; Eixmann, R.; Freudenthaler, V.; Ginoux, P.; Komguem, L.; Linné, H.; et al. Long-range transport of Saharan dust to northern Europe: The 11-16 October 2001 outbreak observed with EARLINET. J. Geophys. Res. Atmos. 2003, 108. [CrossRef] 
69. Liu, Z.; Omar, A.; Vaughan, M.; Hair, J.; Kittaka, C.; Hu, Y.; Powell, K.; Trepte, C.; Winker, D.; Hostetler, C.; et al. CALIPSO lidar observations of the optical properties of Saharan dust: A case study of long-range transport. J. Geophys. Res. Atmos. 2008, 113. [CrossRef]

70. Colette, A.; Favez, O.; Meleux, F.; Chiappini, L.; Haeffelin, M.; Morille, Y.; Malherbe, L.; Papin, A.; Bessagnet, B.; Menut, L.; et al. Assessing in near real time the impact of the April 2010 Eyjafjallajokull ash plume on air quality. Atmos. Environ. 2011, 45, 1217-1221. [CrossRef]

71. Boichu, M.; Clarisse, L.; Péré, J.C.; Herbin, H.; Goloub, P.; Thieuleux, F.; Ducos, F.; Clerbaux, C.; Tanré, D. Temporal variations of flux and altitude of sulfur dioxide emissions during volcanic eruptions: Implications for long-range dispersal of volcanic clouds. Atmos. Chem. Phys. 2015, 15, 8381-8400. [CrossRef]

72. Boylan, J.W.; Russell, A.G. PM and light extinction model performance metrics, goals, and criteria for three-dimensional air quality models. Atmos. Environ. 2006, 40, 4946-4959. [CrossRef]

73. Tao, J.; Zhang, L.; Engling, G.; Zhang, R.; Yang, Y.; Cao, J. Chemical composition of PM 2.5 in an urban environment in Chengdu, China : Importance of springtime dust storms and biomass burning. Atmos. Res. 2013, 122, 270-283. [CrossRef]

74. Wang, Y.; Zhang, X.; Arimoto, R. The contribution from distant dust sources to the atmospheric particulate matter loadings at XiAn, China during spring. Sci. Total Environ. 2006, 368, 875-883. [CrossRef] [PubMed]

75. Liao, T.; Wang, S.; Ai, J.; Gui, K.; Duan, B.; Zhao, Q.; Zhang, X.; Jiang, W.; Sun, Y. Heavy pollution episodes, transport pathways and potential sources of PM2.5 during the winter of 2013 in Chengdu (China). Sci. Total Environ. 2017, 584-585, 1056-1065. [CrossRef] [PubMed]

76. Lang, J.; Zhang, Y.; Zhou, Y.; Cheng, S.; Chen, D.; Guo, X.; Chen, S.; Li, X.; Xing, X.; Wang, H. Trends of PM2.5 and Chemical Composition in Beijing, 2000-2015. Aerosol Air Qual. Res. 2017, 17, 412-425. [CrossRef]

77. Shi, G.L.; Tian, Y.Z.; Ma, T.; Song, D.L.; Zhou, L.D.; Han, B.; Feng, Y.C.; Russell, A.G. Size distribution, directional source contributions and pollution status of PM from Chengdu, China during a long-term sampling campaign. J. Environ. Sci. 2017, 56, 1-11. [CrossRef]

78. Wang, H.; Qiao, L.; Lou, S.; Zhou, M.; Ding, A.; Huang, H.; Chen, J.; Wang, Q.; Tao, S.; Chen, C.; et al. Chemical composition of PM2.5 and meteorological impact among three years in urban Shanghai, China. J. Clean. Prod. 2016, 112, 1302-1311. doi:10.1016/j.jclepro.2015.04.099. [CrossRef]

(C) 2020 by the authors. Licensee MDPI, Basel, Switzerland. This article is an open access article distributed under the terms and conditions of the Creative Commons Attribution (CC BY) license (http://creativecommons.org/licenses/by/4.0/). 